OPEN ACCESS

Edited by:

Yibo Yang,

Institute of Tibetan Plateau Research

(CAS), China

Reviewed by:

Xiubin Lin,

Zhejiang University, China

Xin Wang,

Lanzhou University, China

Honghong Wei,

Institute of Tibetan Plateau Research

(CAS), China

${ }^{*}$ Correspondence:

Dongliang Liu

pillar131@163.com

Specialty section:

This article was submitted to Structural Geology and Tectonics,

a section of the journal

Frontiers in Earth Science

Received: 14 July 2021

Accepted: 30 August 2021

Published: 10 September 2021

Citation:

Wang P, Liu D, Li H, Chevalier M-L, Wang Y, Pan J, Zheng Y, Ge C, Bai M and Wang $S$ (2021) Sedimentary

Provenance Changes Constrain the Eocene Initial Uplift of the Central

Pamir, NW Tibetan Plateau.

Front. Earth Sci. 9:741194.

doi: 10.3389/feart.2021.741194

\section{Sedimentary Provenance Changes Constrain the Eocene Initial Uplift of the Central Pamir, NW Tibetan Plateau}

\author{
Ping Wang ${ }^{1,2}$, Dongliang Liu ${ }^{1,3 *}$, Haibing $\mathrm{Li}^{1,3}$, Marie-Luce Chevalier ${ }^{1,3}$, Yadong Wang ${ }^{4}$, \\ Jiawei Pan ${ }^{1,3}$, Yong Zheng ${ }^{1,3}$, Chenglong $\mathrm{Ge}^{1,5}$, Mingkun Bai ${ }^{1,5}$ and Shiguang Wang ${ }^{6}$ \\ ${ }^{1}$ Key Laboratory of Deep-Earth Dynamics of Ministry of Natural Resources, Institute of Geology, Chinese Academy of Geological \\ Sciences, Beijing, China, ${ }^{2}$ Geophysical Exploration Center, China Earthquake Administration, Zhengzhou, China, ${ }^{3}$ Southern \\ Marine Science and Engineering Guangdong Laboratory (Guangzhou), Guangzhou, China, ${ }^{4}$ Northwest Institute of Eco- \\ Environment and Resources, China Academy of Sciences, Gansu Lanzhou, China, ${ }^{5}$ School of Earth and Space Sciences, Peking \\ University, Beijing, China, ${ }^{6}$ National Institute of Natural Hazards, MEMC, Beijing, China
}

The Pamir Plateau region of the Northwestern Tibetan Plateau forms a prominent tectonic salient, separating the Tajik and Tarim basins. However, the topographic evolution of the Pamir Plateau remains elusive, despite the key role of this region played in the retreat of the Paratethys Ocean and in aridification across Central Asia. Therefore, the SW Tarim and Tajik basins are prime locations to decipher the geological history of the Pamir Plateau. Here, we present detrital zircon U/Pb and apatite fission-track (DAFT) ages from the Keliyang section of the SW Tarim Basin. DAFT ages show that sediments had three components during the Late Cretaceous and two components since the Oligocene. Detrital zircon U/Pb ages mainly cluster between 400 and 500 Ma during the Late Cretaceous, and coincide with ages of the Songpan-Ganzi and the West Kunlun Mountains. In contrast, detrital zircon U/Pb ages in the Eocene sediments are centered at around 200-300 Ma and 40-70 Ma, with a peak at $45 \mathrm{Ma}$, consistent with data from the Central Pamir and the West Kunlun Mountains. The $45 \mathrm{Ma}$ peak in detrital zircon U/Pb ages since the Eocene indicates a new sedimentary source from the Central Pamir. Non-metric multidimensional scaling (MDS) analyses also show that the sedimentary source was closer to the Central Pamir after the Eocene, when compared to the Late Cretaceous. The result shows a clear Eocene provenance change in the Keliyang area. Moreover, this Eocene provenance shift has been detected in previous studies, in both the Tajik and Tarim basins, suggesting that the entire Central Pamir region likely experienced quasi-simultaneous abrupt uplift and paleo-geomorphological changes during the Eocene.

Keywords: pamir plateau, west kunlun mountains, detrital apatite fission track, detrital zircon $\mathrm{U} / \mathrm{Pb}$ age, uplift

\section{INTRODUCTION}

The formation of the Tibetan Plateau is one of the most important Cenozoic geological events, and caused marine and terrestrial transformation, intracontinental earthquakes, and global climate change (Molnar et al., 2010; Molnar and Tapponnier, 1975; Yin and Harrison, 2000). The Pamir Plateau is an important part of the Western Himalayan Syntaxis in the NW Tibetan Plateau 


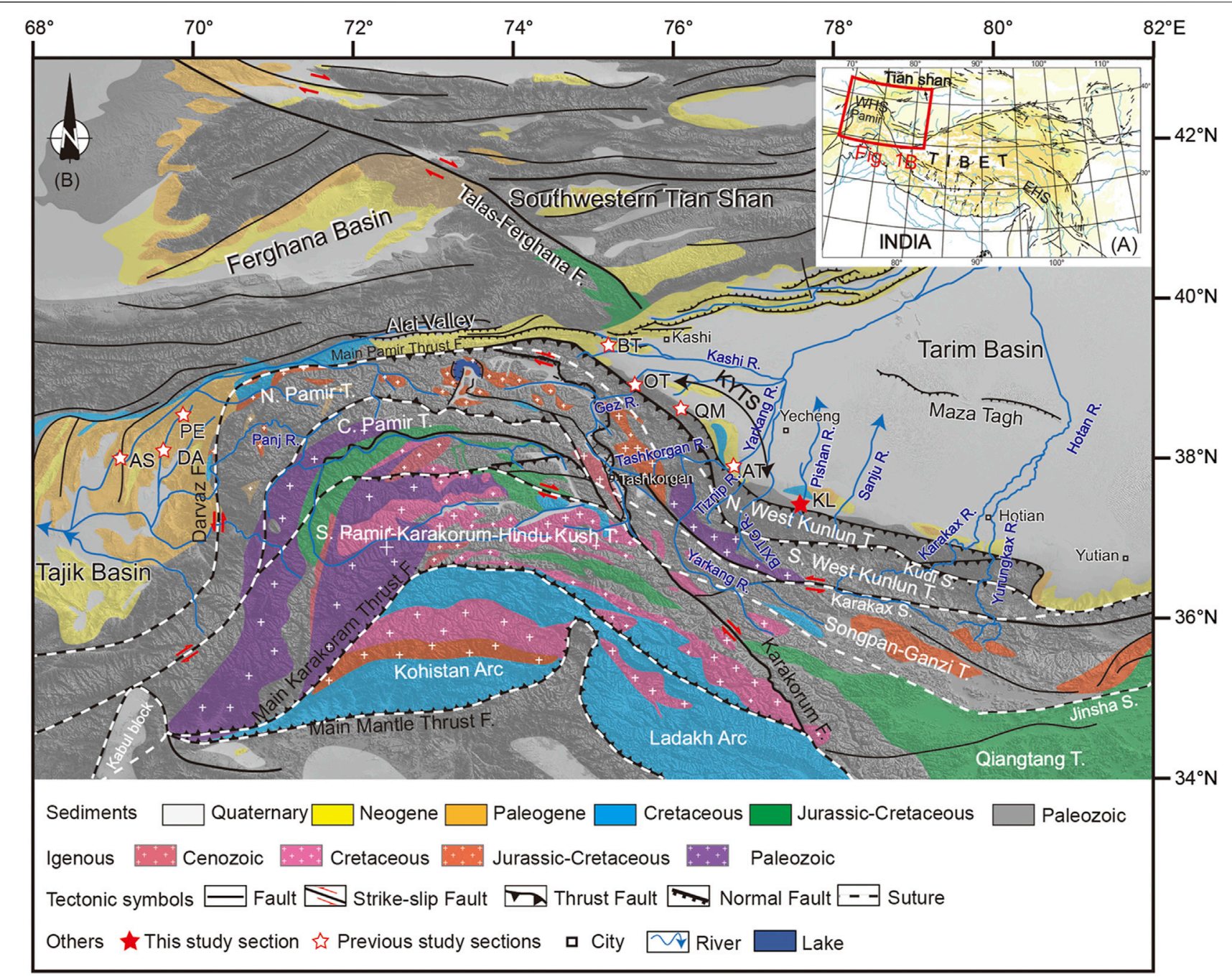

FIGURE 1 | (A) Tectonic map with major active faults of the Tibetan Plateau and surrounding area (modified from Tapponnier et al., 2001). (B) Geological map of the Pamir-West Kunlun and the surrounding area [modified from Bande et al. (2017), Bershaw et al. (2012), Cao et al. (2015), Carrapa et al. (2015) and Jepson et al. (2018)]. $\mathrm{T}$. . = Terranes; S. = Suture; F. = Fault; R. = River; DA = Dashtijum section; AS = Asku section; PE = Peshtova section; $\mathrm{BT}=$ Bora Tokay section; OT = Oytag section; QM = Qimugen section; AT = Aertashi section; KY = Keliyang section; N. Pamir = North Pamir; C. Pamir = Central Pamir; N. Kunlun T = North Kunlun Terrane; KYTS = Kashgar-Yecheng Transfer System.

(Figure 1A). Numerous studies have focused on understanding the tectonic activities of this region (Cowgill, 2009; Sobel et al., 2013; Wei et al., 2013; Yang et al., 2014; Kufner et al., 2016; Liu et al., 2017; Rutte et al., 2017; Chen et al., 2018; Li et al., 2020), the Paratethys Ocean retreat (Bosboom et al., 2014; Wang et al., 2014; Carrapa et al., 2015; Sun et al., 2016a; Bosboom et al., 2017; Kaya et al., 2019; Wang et al., 2019; Sun et al., 2020) and coincident aridification across Central Asia (Zhang et al., 2007a; Zhang et al., 2007b; Huber and Goldner, 2012; Caves et al., 2014; Licht et al., 2014). The Pamir Plateau and the SW Tian Shan Mountains formed a geographic barrier that blocks the transport of moisture by the westerlies, leading to stepwise aridification across Central Asia and formation of the Taklimakan Desert (Sun and Liu, 2006; Zheng et al., 2015a). Competing models between tectonics and sea-level change show that tectonic uplift of the Pamir Plateau was the dominant cause for the Paratethys retreat (Zhang et al., 2007a; Carrapa et al., 2015; Kaya et al., 2019; Sun et al., 2020), but the evolution history of the Pamir Plateau remains unclear.

Previous studies suggest a stepwise exhumation or uplift history of the Pamir, as follows. 1) Late Paleocene to Oligocene initial activities (Cheng et al., 2011; Carrapa et al., 2015; Sun et al., 2016b; Sun et al., 2020); 2) Late Oligocene accelerating uplift (Blayney et al., 2016; Blayney et al., 2019; Wang et al., 2019); 3) Mid-Miocene to Late Miocene rapid uplift that has continued to the present day (Sobel and Dumitru, 1997; Blayney et al., 2019). However, the timing and magnitude of each episodic uplift are debatable. Furthermore, these wide-ranging age estimates limit our understanding of the geological history of the Pamir Plateau and of how its formation links with evidence for climate change. 
The SW Tarim and Tajik basins are foreland basins related to flexural loading of the Pamir-West Kunlun Mountains, and are separated by the Pamir salient to the east and west. These basins were connected by the Paratethys during the Early Cenozoic, before the northward indentation of the Pamir salient (Yin et al., 2002; Carrapa et al., 2015; Sun et al., 2016b; Chapman et al., 2019). Sediments in these basins contain important information about the uplift and erosion history of adjacent mountains, providing an ideal opportunity to investigate the geological history of the ranges. Provenance analysis is a powerful method to reveal spatio-temporal changes of the sediment sources (Cawood et al., 2012; Nie et al., 2014). Here, we use detrital zircon $\mathrm{U} / \mathrm{Pb}$ and DAFT ages for the Cretaceous-Oligocene sediments from the Keliyang section in the SW Tarim Basin, together with data from previous studies in the Tarim and Tajik basins, to characterize source areas, investigate provenance variations, and constrain the time of mountain building of nearby ranges.

\section{GEOLOGIC BACKGROUND}

\section{The Pamir Plateau and West Kunlun Mountains}

The Pamir Plateau constitutes a region of the NW Tibetan Plateau, with the SW Tian Shan and Alai Valley to the north. The Pamir Plateau is a prominent feature separating the Tarim and Tajik basins to the east and west, respectively (Figure 1B). The Pamir Plateau contains several terranes that were accreted onto Eurasia from the Late Paleozoic to the Mesozoic (Schwab et al., 2004; Robinson et al., 2012; Angiolini et al., 2013). From north to south, this plateau can be divided into the North Pamir, the Central Pamir and the South Pamir, which probably correlate with the southern block of the Songpan-Ganzi terrane, the Qiangtang terrane and the Lhasa terrane (Schwab et al., 2004; Cowgill, 2009).

The North Pamir region, bordered by the Main Pamir Thrust (MPT) to the north and the Tanymas suture to the south, is composed of predominantly Paleozoic and Triassic sedimentary rocks, metamorphic sedimentary and metamorphic volcanic rocks, Permian sedimentary and metamorphic volcanic rocks and Triassic turbidites intruded by Triassic-Jurassic granitoid rocks (Schwab et al., 2004; Schmidt et al., 2011; Ding et al., 2013). The Central Pamir region is bordered by the Rushan-Pshart zone to the south, and consists of Paleozoic and Triassic-Jurassic (meta) sedimentary rocks. Magmatic rocks are mainly from the Cretaceous (80-70 Ma), Eocene (42-36 Ma) and Miocene (20-10 Ma) (Schwab et al., 2004; Rutte et al., 2017; Chapman et al., 2018b). The South Pamir is bordered by the Wakhan tirich boundary to the south, which is composed of Paleozoic or Triassic-Jurassic sedimentary rocks and metamorphic sedimentary rocks, as well as Cretaceous and Cenozoic magmatic and metamorphic rocks (Schwab et al., 2004; Blayney et al., 2016).

The SE Pamir Plateau connects with the West Kunlun and forms the Pamir-West Kunlun transition zone. This region is dominated by Precambrian and Paleozoic sedimentary and metasedimentary rocks, with abundant Paleozoic and Triassic intrusive rocks (Blayney et al., 2016). The West Kunlun is separated from the Tarim basin by the Kashi-Yecheng transfer system (KYTS) and the Tiklik fault to the north, and is divided into the northern and southern subterranes by the Tam Karaul thrust (Kudi suture zone). This region is mainly composed of Precambrian and Paleozoic metamorphic sedimentary rocks, and Paleozoic intrusive rocks (Cowgill et al., 2003; Liu et al., 2015; Schwab et al., 2004; Xiao et al., 2002, 2003). The active left-lateral Karakax fault separates the West Kunlun from the SongpanGanzi terrane, which consists predominantly of Triassic sedimentary rocks and Jurassic-Triassic intrusive rocks (Yin and Harrison, 2000). The Jinsha suture zone separates the Tianshuihai terrane from Songpan-Ganzi, and consists predominantly of Triassic-Cretaceous (meta) sedimentary rocks overlying the Paleozoic basement (Matte et al., 1996; Schwab et al., 2004; Robinson et al., 2012).

\section{The Tarim Basin}

The Tarim Basin, located between the Tian Shan (to the north), the West Kunlun Mountains (to the south), the Pamir Plateau (to the west) and the Altyn Tagh Mountains (to the east), is a large rhomb-shaped geomorphic feature close to the NW Tibetan Plateau. Large amounts of erosion materials from the surrounding mountain belts have filled the Tarim Basin, creating $>10 \mathrm{~km}$ thick Mesozoic and Cenozoic strata (Yang and Liu, 2002).

The Cenozoic strata have been divided into the Paleogene Kashi, the Miocene Wuqia groups, and the Atushi and Xiyu Formations. The Kashi group $\left(\mathrm{E}_{\mathrm{k}}\right)$ is composed of the Aertashi $\left(\mathrm{E}_{1}^{\mathrm{a}}\right)$, Qimugen $\left(\mathrm{E}_{1-2}{ }^{\mathrm{q}}\right)$, Kalatar $\left(\mathrm{E}_{2}^{\mathrm{k}}\right)$, Wulagen $\left(\mathrm{E}_{2}{ }^{\mathrm{W}}\right)$ and Bashibulake $\left(\mathrm{E}_{2-3}{ }^{\mathrm{b}}\right)$ Formations in chronological order, which record a series of marine transgressions-regressions (Bosboom et al., 2014; Sun et al., 2016a).

Based on dating a volcanic ash bed as $\sim 11 \mathrm{Ma}$ (Zheng et al., 2015a), the stratigraphic age has been reclassified, although whether it is a volcanic ash bed remains debated (Zheng et al., 2015b; Sun et al., 2015). Assigned ages are > 41 Ma for the Aertashi to Wulagen Formations, $\sim 41$ to $36.5 \mathrm{Ma}$ for the Bashibulake Formation, $\sim 33.0$ to $22.6 \mathrm{Ma}$ for the Wuqia Group (including the Keziluoyi, Anjuan and Pakabulake Formations), $\sim 22.6$ to $15 \mathrm{Ma}$ for the Artux Formation, and $<\sim 15 \mathrm{Ma}$ for the Xiyu Formation (Zheng et al., 2015a).

\section{SAMPLING AND ANALYSES}

\section{Sampling of the Keliyang Section of the Tarim Basin}

The Keliyang section is located near the southern margin of the Tarim Basin. Drilling data show that the core of the Keliyang anticline is composed of Jurassic and Cretaceous sediments (Cheng et al., 2011). The Paleogene strata are overthrust by Mesozoic strata. The Mesozoic-Cenozoic strata of the whole anticline are relatively upright, due to passive uplift (Cheng et al., 2011). The Keliyang section (from $37^{\circ} 16^{\prime} 12.33^{\prime \prime} \mathrm{N}$, $77^{\circ} 51^{\prime} 42.51^{\prime \prime} \mathrm{E}$ to $\left.37^{\circ} 18^{\prime} 47.82^{\prime \prime} \mathrm{N}, \quad 77^{\circ} 51^{\prime} 36.08^{\prime \prime} \mathrm{E}\right)$ has a 


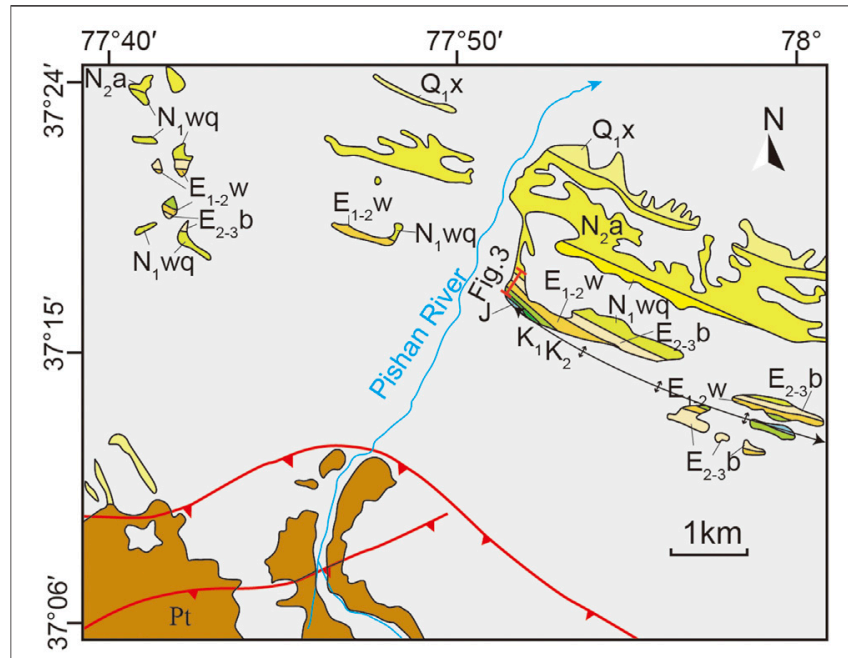

FIGURE 2 | Geological sketch map of the Keliyang area in the SW Tarim Basin (modified after Shaanxi Geological Bureau, 2006). $Q_{1}{ }^{x}$, Xiyu Formation; $\mathrm{N}_{2}{ }^{a}$, Artushi Formation; $\mathrm{E}_{2-3}{ }^{\mathrm{b}}$, Bashiibulake Formation; $\mathrm{E}_{1-2}{ }^{\mathrm{W}}$, AertashiQimugen-Kalatar-Wulagen Formations; $\mathrm{K}_{2}$, Upper Cretaceous; $\mathrm{K}_{1}$, Lower Cretaceous; J, Jurassic; Pt, Paleozoic. lacustrine-delta facies (Sun et al., 2016a). The lower part of this section consists of purplish-red gravelly sandstone, which is interpreted as the terrestrial facies sediments. The middle part consists of interbedded gray limestone, gray-green mudstone and gypsum, which is interpreted as marine-terrestrial interbedded facies. The upper part is dominated by orange-red sandstone and yellow sandstone, is which interpreted as lacustrine and delta facies. The last marine regression in the Tarim Basin occurred at $\sim 40 \mathrm{Ma}$ (Bosboom et al., 2014; Sun et al., 2016a; Kaya et al., 2019). To gain sedimentary provenance information in this section, we collected four samples to represent before (KLY-1), during (KLY-3), and after (KLY-6 and KLY-7) Paratethys regression. These samples were analyzed using detrital apatite fission track and/or zircon $\mathrm{U} / \mathrm{Pb}$ dating methods (Table 1).

We use previous high resolution magnetostratigraphy (Sun et al., 2016a) to quantify the depositional ages of KLY-3 and KLY6 as $\sim 40$ and $\sim 32 \mathrm{Ma}$, respectively (Table 1). According to the true thickness (between KLY-3 and KLY-1) and average sedimentary deposition rates (for the bottom segment of the magnetostratigraphic profile), KLY-1 is estimated to have been deposited at $\sim 56 \mathrm{Ma}$ (Figure 3 and Figure 4). However, the lithology of KLY-1 is consistent with Upper Cretaceous gravel-

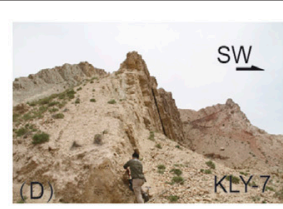

Elevation $(\mathrm{m})$

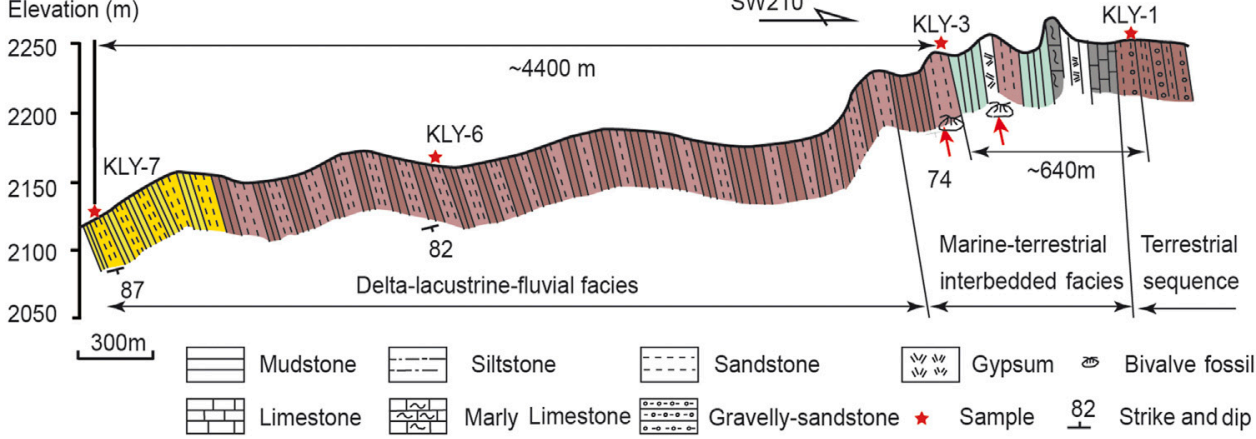

FIGURE 3 | Cross-section of the Keliyang area in the SW Tarim Basin (A), Sandstones intercalated with gravel; (B), Green mudstones with interbeds of siltstones; (C), Orange-red sandstone; (D), Light yellow sandstone.

thickness of about 5-6 km and is mainly composed of Jurassic, Cretaceous, Paleogene and Neogene strata, of which the Paleogene strata are the best exposed (Figure 2). All the Paleogene strata show structural inversion with a dip toward the SE at angles of $75-85^{\circ}$, and are mainly composed of delta, fluvial and lacustrine facies sediments (Figure 3).

We did not make a detailed grouping of strata, to avoid the strong debate on the chronologies of the Cenozoic strata. Based on the sedimentary environment and field observation, the Keliyang section can be roughly divided into three units of terrestrial facies, marine-terrestrial interbedded facies, and bearing coarse sandstone strata in the SW Tarim Basin (Si et al., 2007; Sun et al., 2016b; Chen et al., 2018; Li et al., 2021), and the uncorrected magnetostratigraphic age may be affected by inaccuracies in the sedimentation rate or sedimentary discontinuities. On the other hand, detrital zircon $\mathrm{U} / \mathrm{Pb}$ ages of KLY-3 and KLY-7 yielded the youngest single zircon ages of $43.7 \mathrm{Ma}(n=1)$ and $23.1 \mathrm{Ma}(n=1)$. The lag time between the youngest detrital zircon $\mathrm{U} / \mathrm{Pb}$ age $(43.7 \mathrm{Ma})$ and the magnetostratigraphic depositional age $(40 \mathrm{Ma})$ is roughly $4 \mathrm{Ma}$, which is a reasonable time frame from crystallization to deposition. The KLY-7 sample was not included in previous 
TABLE 1 | Sampling information for the Keliyang Section in the SW Tarim Basin. The* symbol represents ages based on high precision magnetostratigraphy from Sun et al. (2016a); and the+symbol represents ages constrained by the youngest detrital zircon U/Pb age.

\begin{tabular}{|c|c|c|c|c|c|}
\hline ID & Latitude and Longitude & Elevation/m & Strike and dip & Deposition age & Lithology \\
\hline KLY-1 & N $37^{\circ} 16^{\prime} 12.3^{\prime \prime}$, E $77^{\circ} 51^{\prime} 42.5^{\prime \prime}$ & 2,194 & & Late Cretaceous & Gravelly sandstone \\
\hline KLY-3 & N $37^{\circ} 16^{\prime} 27.6^{\prime \prime}$, E $77^{\circ} 51^{\prime} 25.3^{\prime \prime}$ & 2,195 & $196^{\circ} \angle 74^{\circ}$ & $\sim 40 \mathrm{Ma}^{\star}$ & Siltstone \\
\hline KLY-6 & N $37^{\circ} 17^{\prime} 55.9^{\prime \prime}$, E $77^{\circ} 51^{\prime} 48.1^{\prime \prime}$ & 2,145 & $357^{\circ} \angle 71^{\circ}$ & $\sim 32 \mathrm{Ma}^{*}$ & Sandstone \\
\hline KLY-7 & N $37^{\circ} 18^{\prime} 47.8^{\prime \prime}$, E $77^{\circ} 51^{\prime} 36.1^{\prime \prime}$ & 2,117 & $201^{\circ} \angle 87^{\circ}$ & $\sim 23.1 \mathrm{Ma}^{+}$ & Sandstone \\
\hline
\end{tabular}

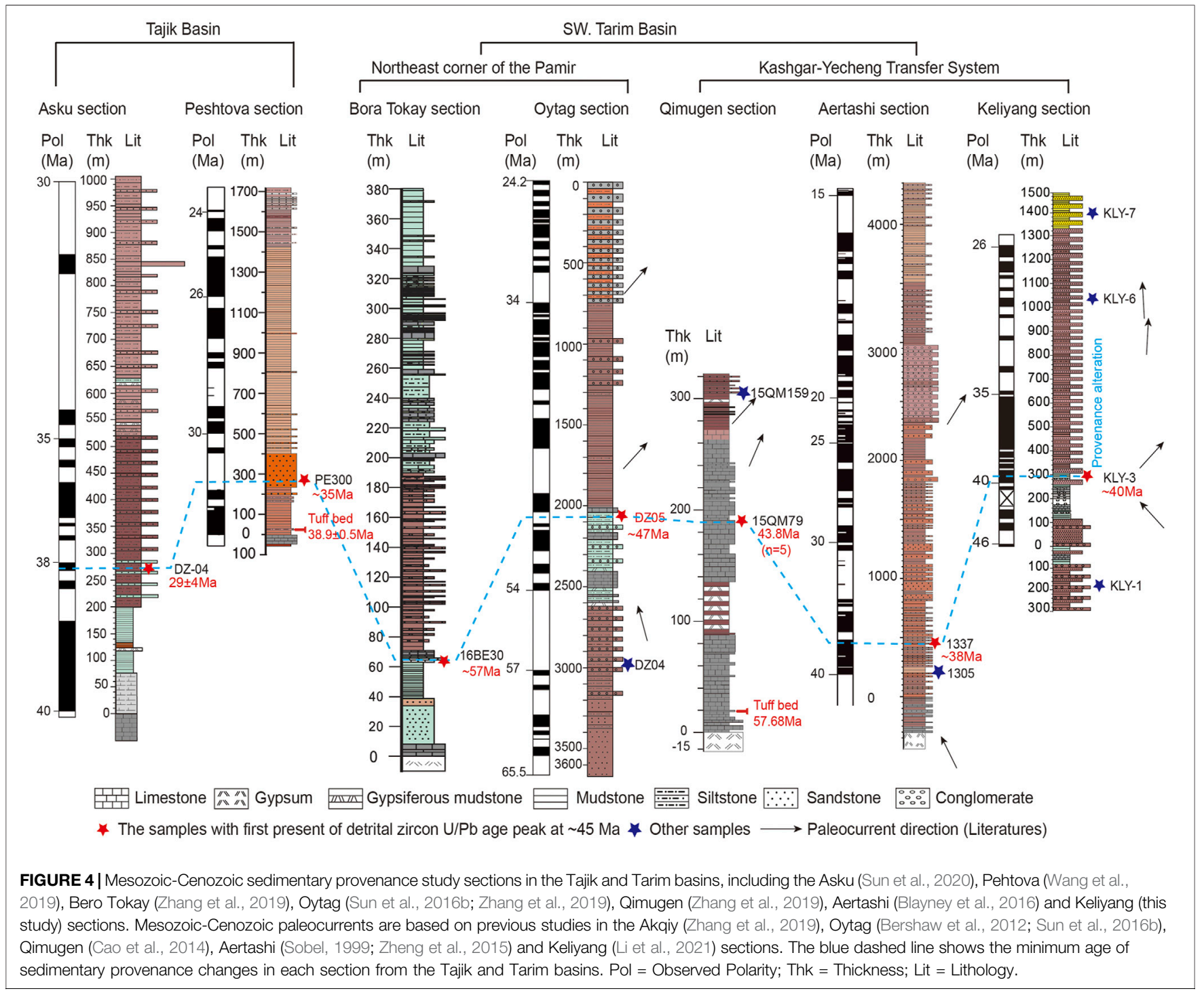

magnetostratigraphic profiles, but the youngest detrital single zircon $\mathrm{U} / \mathrm{Pb}$ age can be used to determine its depositional age (Dickinson and Gehrels, 2009). The youngest detrital zircon U/Pb age of KLY-7 was $23.1 \mathrm{Ma}$, so KLY-7 is assigned a depositional age younger than $23.1 \mathrm{Ma}$ (Figure 4).

\section{Analytical Methods}

Detrital apatite fission-track (DAFT) measurements were carried out using the external detector method. Apatite was separated from rock samples by magnetic and gravity separation, embedded in epoxy resin, polished to expose internal crystal surfaces, and etched in $5 \mathrm{~N} \mathrm{HNO}_{3}$ at $20^{\circ} \mathrm{C}$ for $20 \mathrm{~s}$ to reveal spontaneous fission tracks. Internal surfaces of the crystals were then covered with low-uranium muscovite external detectors, packed together with CN5 standard dosimeter glasses, and irradiated. Induced tracks were revealed in the muscovite external detectors by etching in $40 \% \mathrm{HF}$ at room temperature for $25 \mathrm{~min}$. DAFT analyses were counted at $\times 1,250$ dry $(\times 100$ objective $)$. FT ages were calculated 
TABLE 2 | Detrital apatite fission track results of the Keliyang section in the SW Tarim Basin.

\begin{tabular}{|c|c|c|c|c|c|c|c|c|}
\hline Sample ID & Deposition age (Ma) & $\mathbf{N}$ & Age range (Ma) & Central age (Ma) & $\mathbf{P}\left(\chi^{2}\right) \%$ & P1 (Percent) & P2 (Percent) & P3 (Percent) \\
\hline KLY-1 & $\mathrm{K}_{2}$ & 59 & 35.3-202.7 & $74.7 \pm 3.3$ & 0.0 & $\begin{array}{c}45.8 \pm 5.4 \\
21 \%\end{array}$ & $\begin{array}{c}69.1 \pm 6.4 \\
39 \%\end{array}$ & $\begin{array}{c}96.8 \pm 8.5 \\
40 \%\end{array}$ \\
\hline KLY-6 & $\sim 32 \mathrm{Ma}$ & 33 & 29.2-876.6 & $50 \pm 4.4$ & 0.0 & $\begin{array}{c}35.7 \pm 2.7 \\
64.5 \%\end{array}$ & $\begin{array}{c}80.5 \pm 7.1 \\
35.3 \%\end{array}$ & \\
\hline KLY-7 & $\sim 23 \mathrm{Ma}$ & 24 & $23.7-314.1$ & $68.6 \pm 9.6$ & 0.0 & $\begin{array}{c}25.9 \pm 3.4 \\
29.6 \%\end{array}$ & $\begin{array}{c}80.6 \pm 7.2 \\
70.4 \%\end{array}$ & \\
\hline PE825 & $\sim 28 \mathrm{Ma}$ & 50 & & & 0.0 & $\begin{array}{l}36.9 \pm 3.9 \\
54 \pm 12 \%\end{array}$ & $\begin{array}{l}80.8 \pm 8.9 \\
46 \pm 12 \%\end{array}$ & \\
\hline PE1625 & $\sim 24 \mathrm{Ma}$ & 50 & & & 0.0 & $\begin{array}{c}25.8 \pm 3 \\
64 \pm 15 \%\end{array}$ & $\begin{array}{c}59 \pm 12 \\
36 \pm 15 \%\end{array}$ & \\
\hline PE1680 & $\sim 23.5 \mathrm{Ma}$ & 50 & & & 0.0 & $\begin{array}{c}36.5 \pm 2.1 \\
92.4 \pm 5.2 \%\end{array}$ & $\begin{array}{c}102 \pm 22 \\
7.6 \pm 5.2 \%\end{array}$ & \\
\hline
\end{tabular}

$K_{2}$ : Late Cretaceous. N: total number of grains counted. $P(\chi 2): \chi 2$ probability that the single-grain ages represent one population. P1, $P 2$ and $P 3$ are peak ages according to the Radial Plotter. The percentage of grains in a specific peak is also given. Samples prefixed "PE" are from Wang et al. (2019) from the Tajik Basin.

using the $\xi$-calibration method, with an overall weighted mean $\xi$ of $272.78 \pm 15.99 \mathrm{a} / \mathrm{cm}^{2}$. DAFT analyses were performed at the Key Laboratory of Petroleum Resources, Northwest Institute of Eco-Environment and Resources at the Chinese Academy of Sciences.

After crushing, zircons were separated by standard heavy liquid and magnetic techniques. Zircon grains were randomly picked and mounted onto adhesive tape, enclosed in epoxy resin, and polished to about half their thickness. After being photographed under reflected and transmitted light, samples were prepared for cathodoluminescence (CL) imaging and $\mathrm{U} / \mathrm{Pb}$ dating. Zircon $\mathrm{U} / \mathrm{Pb}$ dating was performed using an Agilent 7500a ICP-MS equipped with a 2005M excimer ArF laser ablation system (GeolasPlus) at the China University of Geosciences (Wuhan). A laser spot diameter of $30 \mu \mathrm{m}$ was used. The ICP-MS data calibration (10.7) program was used for data calibration.

The ${ }^{207} \mathrm{~Pb} /{ }^{206} \mathrm{~Pb}$ ages were used to date zircons older than $1,000 \mathrm{Ma}$, and ${ }^{206} \mathrm{~Pb} /{ }^{238} \mathrm{U}$ ages were used to date zircons younger (Black et al., 2003) than 1,000 Ma, due to small amounts of ${ }^{207} \mathrm{~Pb}$ in young zircons limiting precise ${ }^{207} \mathrm{~Pb} /{ }^{206} \mathrm{~Pb}$ dating. To assess the similarity of samples and their potential sources, we use multi-dimensional scaling (MDS) (Vermeesch, 2013) to produce a map of points where similar samples cluster together, which quantifies the distance between the empirical cumulative distribution functions of two samples. The plot axes are non-quantitative.

\section{RESULTS}

\section{Detrital Apatite Fission Track Ages}

KLY-1 contains 59 grains with relatively scattered ages ranging from 35.27 to $202.73 \mathrm{Ma}$, and a central age of $74.7 \pm 3.3 \mathrm{Ma}$. KLY6 has 33 grains with ages between 29.16 and $876.64 \mathrm{Ma}$, and a central age of $50 \pm 4.4 \mathrm{Ma}$. KLY-7 has 24 grains with ages between 23.7 and $314.1 \mathrm{Ma}$, and a central age of $68.6 \pm 9.6 \mathrm{Ma}$.

The DAFT ages of all samples failed the $\chi^{2}$ test $\left(\mathrm{P}\left(\chi^{2}\right)<5 \%\right)$ (Table 2 and Figure 5). The result of KLY-1 can be statistically decomposed into three age components: $45.8 \pm 4 \mathrm{Ma}(21 \%)$, $69.1 \pm 6.4 \mathrm{Ma}(39 \%)$ and $96.8 \pm 8.5 \mathrm{Ma}(40 \%)$. The result of
KLY-6 can be divided into two components with peak ages at $35.7 \pm 2.7 \mathrm{Ma}(64.5 \%)$ and $80.5 \pm 7.1 \mathrm{Ma}(35.3 \%)$. The result of KLY-7 can be divided into two components with peak ages of $25.9 \pm 3.4 \mathrm{Ma}(\mathrm{P} 1)$ and $80.6 \pm 7.2 \mathrm{Ma}(\mathrm{P} 2)$.

\section{Detrital Zircon U/Pb Ages}

Detrital zircon U/Pb ages are shown in Supplementary Table S1 and Figure 6. A total of 116 concordant ages were obtained for KLY-1. The zircon $\mathrm{U} / \mathrm{Pb}$ age spectrum shows age populations between 400 and 2,800 Ma, the majority around $\sim 400-500 \mathrm{Ma}$ $(\sim 81 \%)$ with a peak at $\sim 480 \mathrm{Ma}$. A smaller age population is observed at $\sim 600-900 \mathrm{Ma}$, with peaks at $\sim 640 \mathrm{Ma}$ and $\sim 800 \mathrm{Ma}$. In addition, sporadic distributions are centered at $\sim 1800$ and $\sim 2,600 \mathrm{Ma}$.

A total of 108 concordant ages were obtained for KLY-3, with the youngest age at $43.7 \mathrm{Ma}$. The zircon $\mathrm{U} / \mathrm{Pb}$ age spectrum shows age populations between 44 and 3,200 Ma. Ages range between 0 and $100 \mathrm{Ma}$, with a peak at $\sim 40 \mathrm{Ma} ; 240-500 \mathrm{Ma}$ with peaks at $\sim 280 \mathrm{Ma}$ and $\sim 320 \mathrm{Ma}$; and $\sim 560-720 \mathrm{Ma}$ with peaks at $\sim 580$ and $\sim 640 \mathrm{Ma}$. A few additional ages are scattered at roughly 1,200 Ma, 1,600 Ma, 2,400 Ma and 3,200 Ma.

A total of 119 concordant ages were obtained for KLY-7, with the youngest age at 23.1 Ma. The zircon $\mathrm{U} / \mathrm{Pb}$ age spectrum shows age populations between 23.1 and 2,800 Ma. These are concentrated between 0 and $80 \mathrm{Ma}$ with peaks at $\sim 40$ and $\sim 20 \mathrm{Ma} ; 200-300 \mathrm{Ma}$ with a peak at $\sim 240 \mathrm{Ma} ; 400-500 \mathrm{Ma}$ with a peak at $\sim 440 \mathrm{Ma}$; and $600-1,200 \mathrm{Ma}$ with a peak at $\sim 800 \mathrm{Ma}$. A minor age population occurs between 1,200 and $2000 \mathrm{Ma}$, and there are some scattered ages between $\sim 2,200$ and 2,800 Ma.

\section{INTERPRETATION AND DISCUSSION}

\section{Sedimentary Provenance Changes in the sW Tarim and Tajik Basins \\ The SW Tarim Basin}

In the Keliyang section, the KLY-3 and KLY-7 samples have a younger zircon $\mathrm{U} / \mathrm{Pb}$ age peak at $\sim 45 \mathrm{Ma}$. This obvious difference between the zircon U/Pb age of KLY-1 and KLY-3 suggests that the sedimentary provenance underwent significant alteration 
$A_{\mathrm{KLY} 1(\mathrm{n}=59)}$

Central age $=74.7 \pm 3.3 \mathrm{Ma}(10) \quad 156 \mathrm{Ma}$

Dispersion $=28 \%$

$\mathrm{P}\left(\mathrm{X}^{2}\right)=0.00$

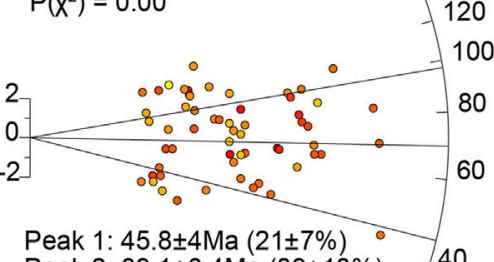

Peak 1: $45.8 \pm 4 \mathrm{Ma}(21 \pm 7 \%)$
Peak 2: $69.1 \pm 6.4 \mathrm{Ma}(39 \pm 13 \%)$

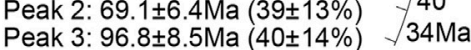

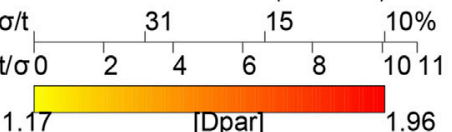

$\begin{array}{lll}1.17 & \text { [Dpar] } & 1.96\end{array}$
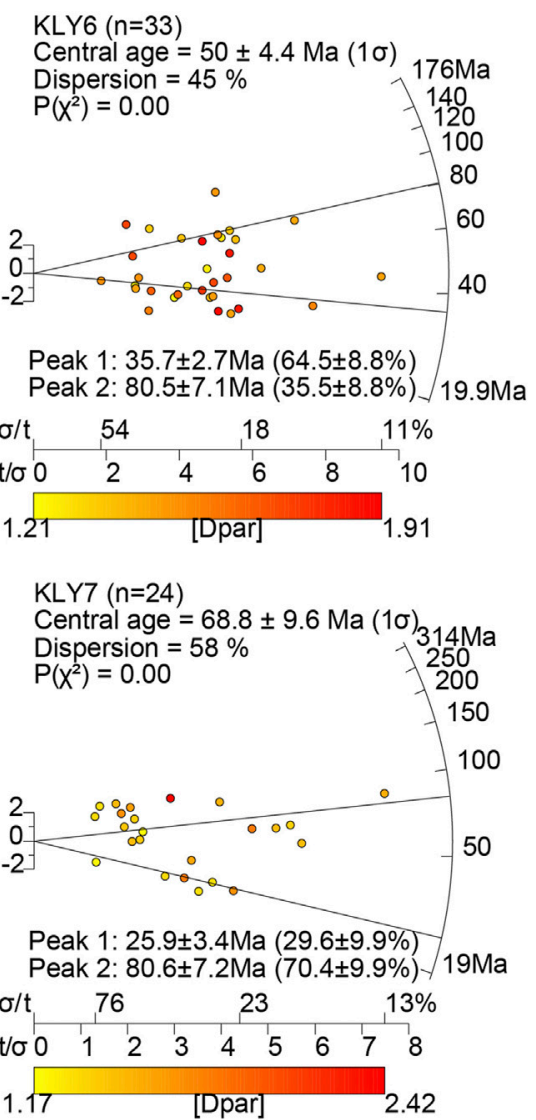
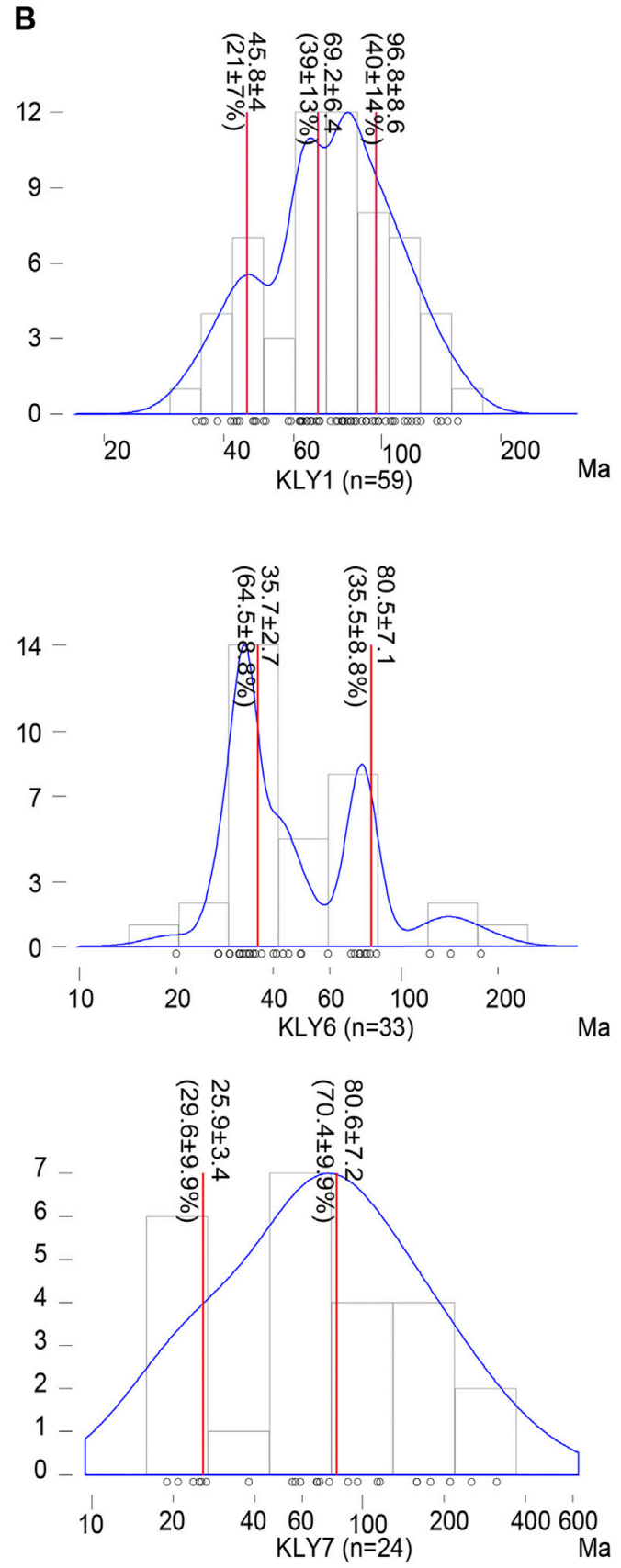

FIGURE 5|Apatite fission-track radial plots (A) and peak age plots (B) of the Keliyang section. In the peak age plots, the blue and red lines represent the fitted curve and peak values, respectively.

from the Late Cretaceous to the Eocene ( $40 \mathrm{Ma})$. MDS provides additional information about the sedimentary change, and is a standard statistical technique to determine the similarity between sediment characteristics and source regions (Vermeesch, 2013). This technique has been successfully used in provenance tracing (Nie et al., 2014; Clift et al., 2017) and river evolution studies (Wang et al., 2020; Sun et al., 2021). In the MDS plots of zircon $\mathrm{U} / \mathrm{Pb}$ data (stress value $=0.9 \%$ ), KLY-1 is statistically separated from the other two samples (Figure 7). In summary, the MDS analyses indicate that the sedimentary source of the Keliyang section changed during the Eocene.

Regional provenance analyses show similar patterns in other sections. Blayney et al. (2016) analyzed detrital zircon U/Pb ages in the Aertashi section to the northwest of the Keliyang section (Figure 4). In the Aertashi section, sediments with a depositional age of roughly $40 \mathrm{Ma}$ (Sample ID =1,305) have almost no zircons with ages of less than $100 \mathrm{Ma}$, while samples with a depositional age of $37.5 \mathrm{Ma}$ (Sample ID =1,337) have a peak in detrital zircon 


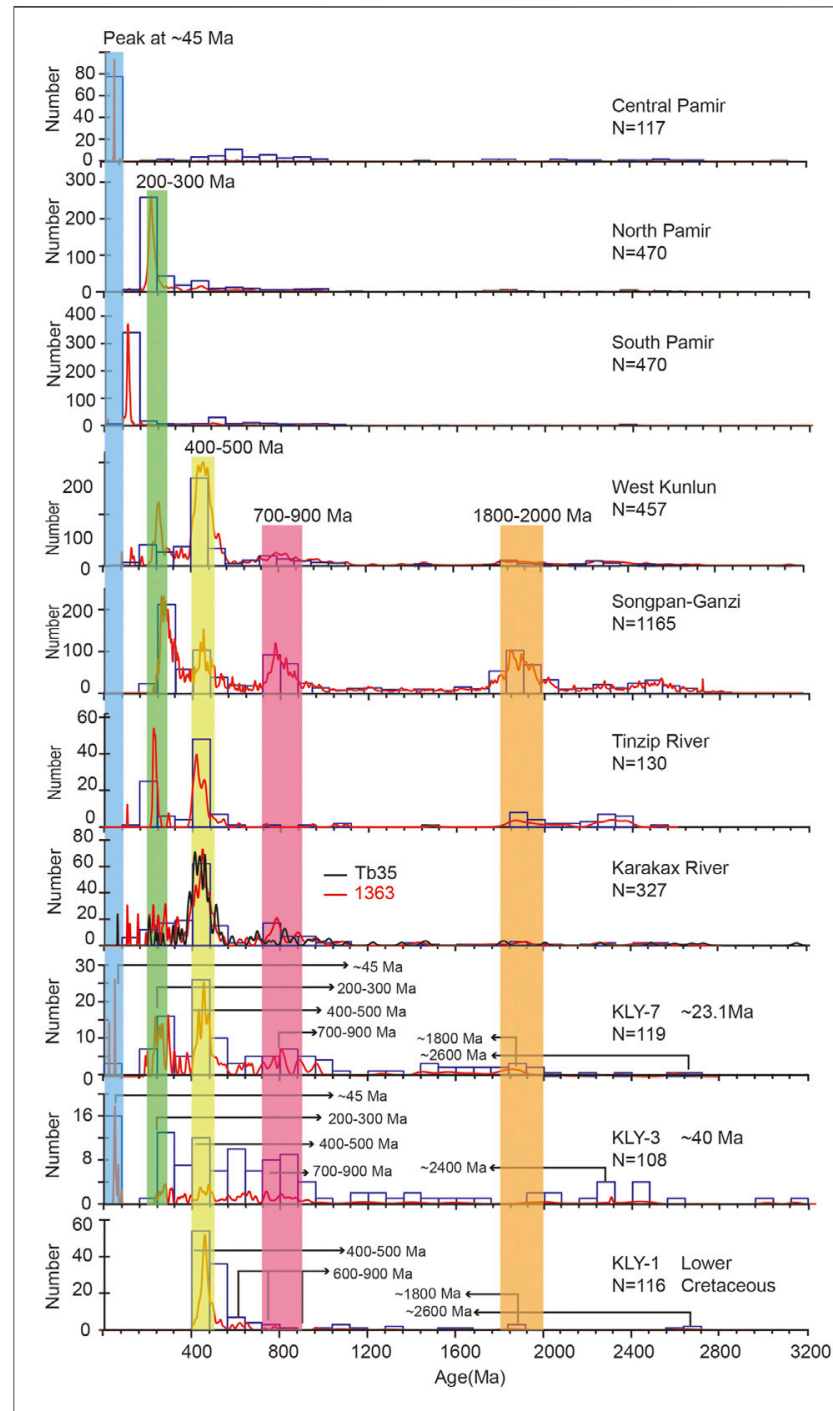

FIGURE 6 | Detrital zircon U/Pb ages from the Keliyang section in the SW Tarim Basin and potential source correlation. The North Pamir provenance is dominated by a 200-300 Ma peak (Carrapa et al., 2014; Blayney et al., 2016; Rittner et al., 2016). The Central Pamir provenance is dominated by a 45 Ma peak (Lukens et al., 2012). The South Pamir provenance is dominated by a peak of $\sim 100 \mathrm{Ma}$ (Blayney et al., 2016). The West Kunlun provenance has two peaks, at 200-300 Ma and 400-500 Ma, with two less prominent peaks at $~ 800$ and $1800 \mathrm{Ma}$ (Blayney et al., 2016). The Songpan-Ganzi provenance has four peaks, at 200-300, 400-500, 700-900 and 1800-2000 Ma (Ding et al., 2013). The modern Tinzip River $(1,344)$ provenance has a double peak at 200-300 and 400-500 Ma (Blayney et al., 2016). The modern Karakax River catchment (1,363, Tb35) provenance has a peak at 400-500 Ma (Blayney et al., 2016; Rittner et al., 2016). N is the number of Concordia zircons. The shaded bars highlight the dominant zircon $\mathrm{U} / \mathrm{Pb}$ age ranges.

$\mathrm{U} / \mathrm{Pb}$ ages at $\sim 45 \mathrm{Ma}$ (Figure 8). Therefore, we constrain the timing of the sedimentary provenance shift to have occurred between 40 and $37.5 \mathrm{Ma}$. To the northwest of the Aertashi section, Zhang et al. (2019) analyzed detrital zircon $\mathrm{U} / \mathrm{Pb}$ ages in the Qimugen, and Bora Tokay sections (Figure 9 in Zhang et al., 2019). In the Qimugen section, the zircon $\mathrm{U} / \mathrm{Pb}$ age peak at $\sim 45$ Ma was first recorded in the Eocene sediments (15QM79 and 15QM159). In the Bora Tokay section, the peak at 45 Ma firstly appeared in the Late Paleocene-Early Eocene sediments (16BE30 and 16BE36). In the Oytag section, Paleocene sediments (DZ01, DZ02, DZ03 and DZ04) exhibit similar detrital zircon age spectra, while the Eocene sediments in this section (DZ05, DZ06, DZ07 and DZ08) have detrital zircon U/Pb ages consistent with the peak at $\sim 45 \mathrm{Ma}$. As sample DZ05 was deposited at $\sim 47 \mathrm{Ma}$, the sedimentary provenance shift must have occurred after this time (Sun et al., 2016b). Rock magnetic analyses corroborate this significant provenance change (Sun et al., 2016b). These findings suggest that the change in sediment provenance occurred before the Late Paleocene-Early Eocene in Bore Tokay, before $\sim 47 \mathrm{Ma}$ in Oytag, during the Eocene in Qimugen, between 40 and $37.5 \mathrm{Ma}$ in Aertashi, and from the Late Cretaceous to $\sim 40 \mathrm{Ma}$ in the Keliyang sections. We constrain the change in sedimentary provenance of the Aertashi section to 40-37.5 Ma (Late Eocene) and assign $40 \mathrm{Ma}$ as the oldest age of the sedimentary provenance change for the sections around the Kashgar-Yecheng Transfer System.

Paleocurrent analyses are used to understand the direction of water flow in the geological past, and are widely used to reconstruct ancient sedimentary source regions and depositional environments (Dickinson et al., 1983). The paleocurrent direction changes provide independent evidence of the Eocene provenance shift (Figure 4). Some paleocurrent results have been published for the Akqiy (Zhang et al., 2019), Oytag (Sobel., 1999; Bershaw et al., 2012), Qimugen (Cao et al., 2014), Aertashi (Sobel., 1999) and Keliyang (Li et al., 2021)

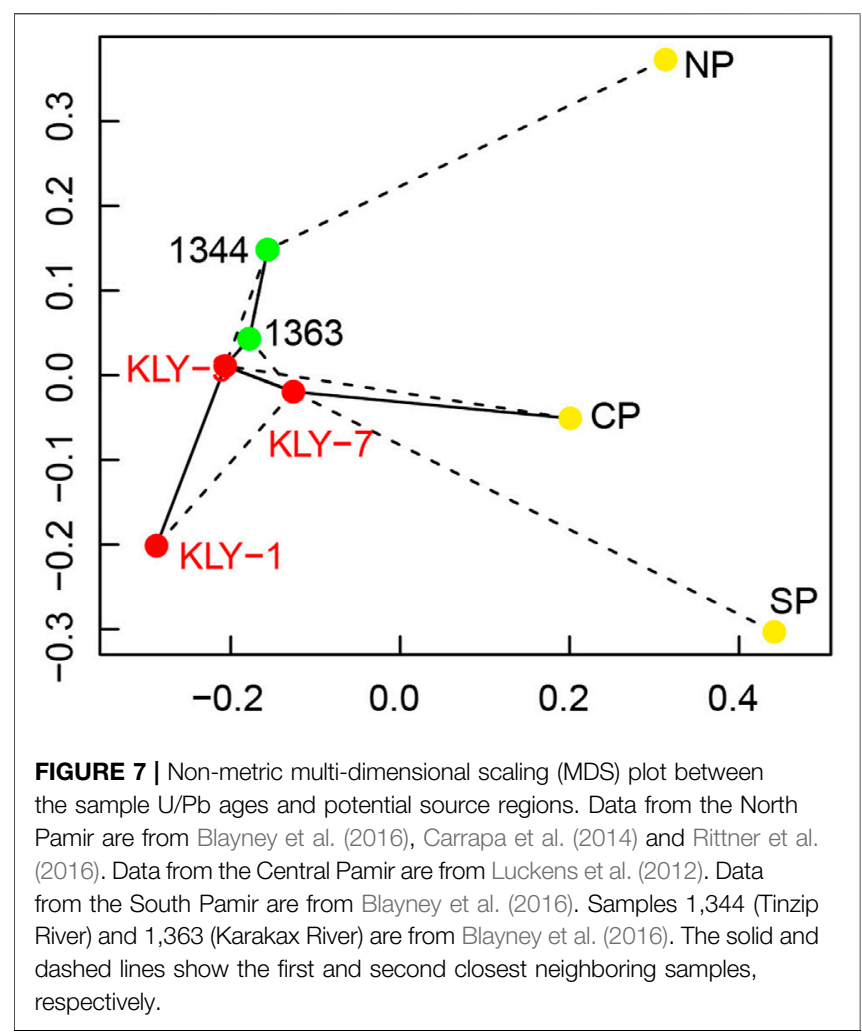



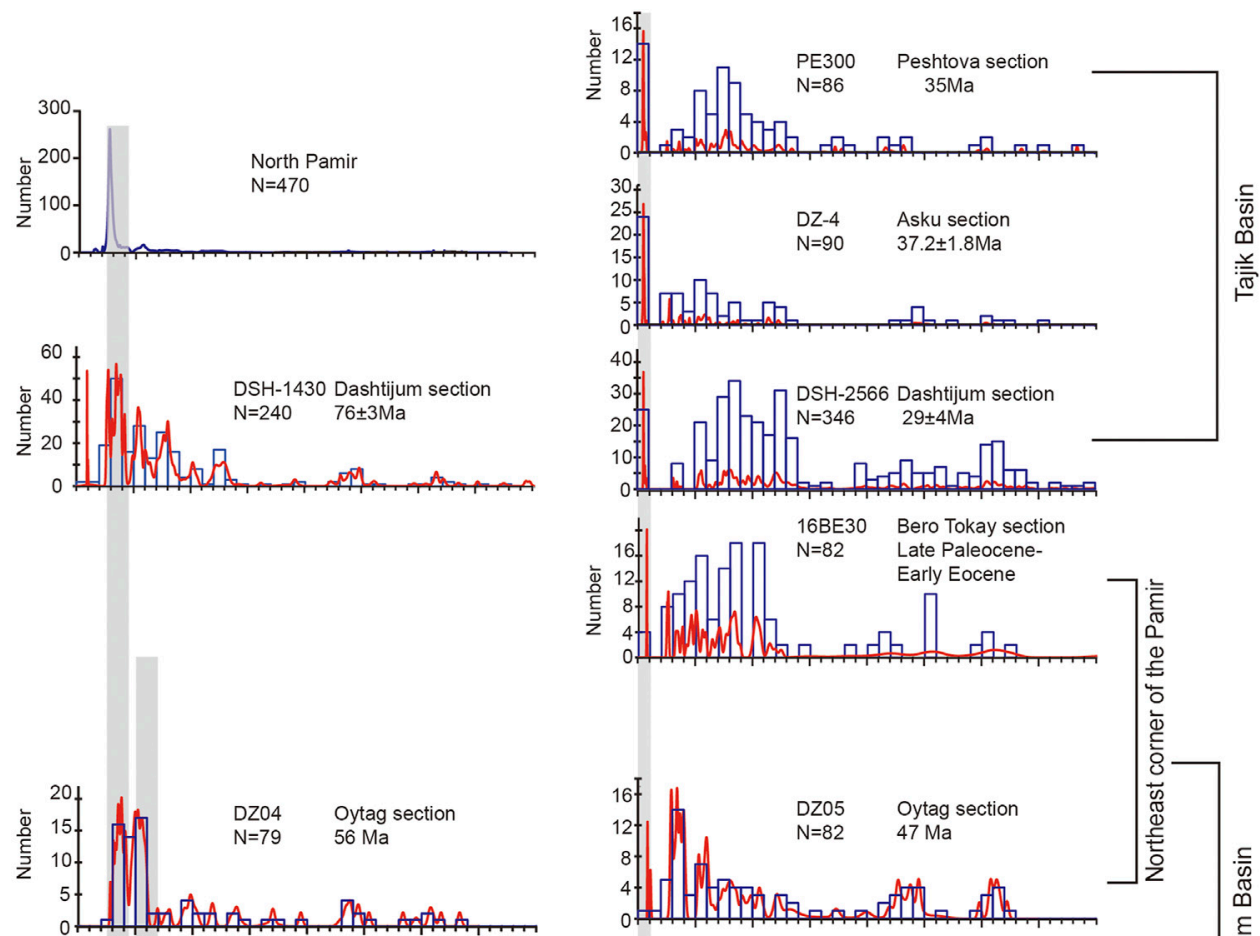

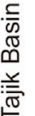
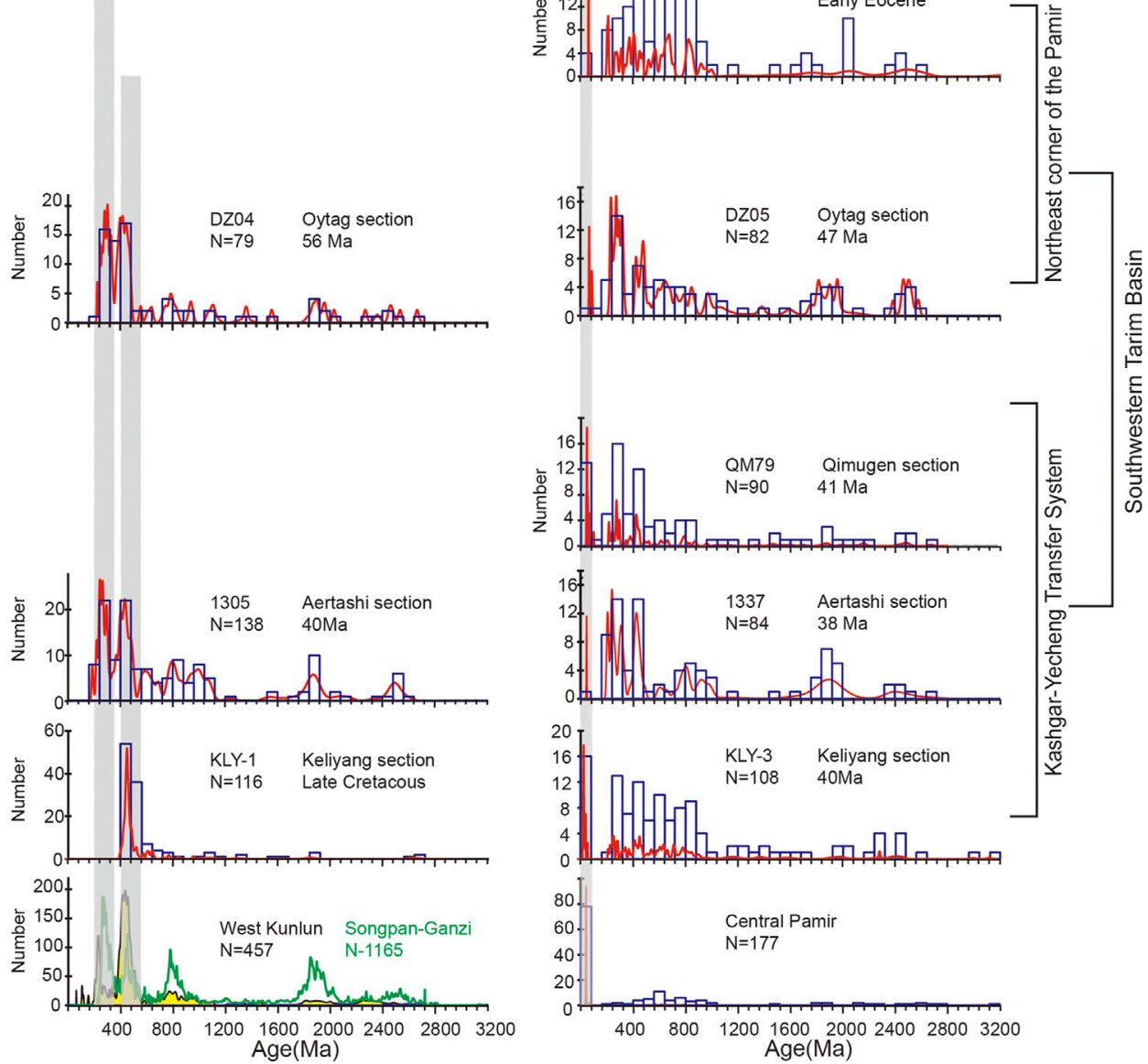

FIGURE 8 | Characterization of source regions and probability density plots of the Bero Tokay, Qytag, Qimugen, Aertashi, Keliyang sections in the Tarim Basin and Dashtjum, Asku, Peshtova sections in the Tajik Basin. Data from the Oytag, Qimugen, Aertashi, Dashtjum, Asku and Peshtova sections are modified from Sun et al. (2016b), Zhang et al. (2019), Blayney et al. (2016), Chapman et al. (2019), Sun et al. (2020), and Carrapa et al. (2015). Detrital zircon U/Pb age plots from North Pamir are modified from (Carrapa et al., 2014; Blayney et al., 2016; Rittner et al., 2016). Detrital zircon U/Pb age plots from West Kunlun are modified from Blayney et al. (2016). Detrital zircon U/Pb age plots from Songpan-Ganzi are modified from Ding et al. (2013). Shaded bars mark peak ages at 400-500 Ma, 200-300 Ma and 45 Ma. The significant Eocene quasi-synchronous sedimentary provenance changes occurred in both the Tarim and Tajik basins.

sections in the SW Tarim Basin. In the Keliyang section, paleocurrent analyses of the Kashi group show that sediments were transported from the southeast, while sediment of the Wuqia group was mainly transported from the southwest ( $\mathrm{Li}$ et al., 2021). In the Qimugen and Aertashi sections, the paleocurrents of the Wuqia Group mainly came from the southwest (Sobel., 1999; Cao et al., 2014), and Early Cretaceous paleocurrents mainly came from the southeast (Sobel., 1999). In the northeastern corner of the Pamir Plateau, the main change in paleocurrent direction may have 
occurred between the Cretaceous and the Paleocene (Figure 6 in Zhang et al., 2019).

\section{The Tajik Basin}

There have also been some sedimentary provenance studies in the Tajik Basin, including the Peshtova, Dashtijum and Asku sections, from northeast to southwest, respectively (Figure 4 and Figure 8) (Chapman et al., 2019; Wang et al., 2019; Sun et al., 2020). In the Peshtova section, the youngest zircon U/Pb age peak at $\sim 45 \mathrm{Ma}$ first appears in sediment with depositional ages of $\sim 35 \mathrm{Ma}$ (Wang et al., 2019). In the Dashtijum section, the zircon $\mathrm{U} / \mathrm{Pb}$ age peak at $\sim 45 \mathrm{Ma}$ occurred in samples with depositional ages between the Late Cretaceous (sample DSH1430 in the Sangoba Formation) and the Oligocene (sample DSH2225 in the Baldshuan Formation). Detrital zircon fission-track analyses identified two components during the Oligocene (sample DSH-2225 in the Baldshuan Formation), compared to one component during the Late Cretaceous (sample DSH-470 in the Schuchi-poyon Formation) (Chapman et al., 2019). In the Asku section, the zircon $\mathrm{U} / \mathrm{Pb}$ age peak at $\sim 45 \mathrm{Ma}$ is observed after $\sim 38 \mathrm{Ma}$ (DZ-04) (Sun et al., 2020). The difference between these three sections is relatively small, suggesting similarities in sedimentary provenance during deposition. As such, we use $\sim 38 \mathrm{Ma}$ as the lower time limit, which belongs to the Late Eocene. More interestingly, detrital apatite fission-track ages have two components, of $\sim 37-25 \mathrm{Ma}$ and $\sim 80-60 \mathrm{Ma}$ (Sample $\mathrm{ID}=$ PE825) in the Peshtova section from the Tajik basin (Figure 3 in Wang et al., 2019), which is similar to that in the Keliyang section (Table 2). This suggests that the sedimentary source of the northwest corner of the Pamir Plateau in the Tajik Basin was likely to be similar to that in Tarim Basin at that time.

\section{Provenance Interpretation}

Geologists compare detrital zircon $\mathrm{U} / \mathrm{Pb}$ ages between basin sediments and closed blocks to deduce potential provenance regions (Cawood et al., 2012; Carrapa et al., 2015; Sun et al., 2016b, 2020; Blayney et al., 2016; Chapman et al., 2019; Zhang et al., 2019). As discussed above, the main paleocurrents in the SW Tarim Basin both came from the south, with sources including the Pamir Plateau, the West Kunlun Mountains and the Songpan-Ganzi terranes. Furthermore, these different regions have different geochronological characteristics (Figure 8). The North Pamir region is dominated by the 200-300 Ma peak in detrital zircon $\mathrm{U} / \mathrm{Pb}$ ages and does not show a 400-500 Ma peak (Schwab et al., 2004; Lukens et al., 2012; Carrapa et al., 2015). The Central Pamir region has a typical peak of $\sim 45 \mathrm{Ma}$ and does not have a peak older than $400 \mathrm{Ma}$ (Lukens et al., 2012). The South Pamir region detrital zircon $\mathrm{U} / \mathrm{Pb}$ ages are mainly distributed around $\sim 100 \mathrm{Ma}$ (Yin and Harrison, 2000; Lukens et al., 2012). The West Kunlun has two peaks, at $\sim 200-300 \mathrm{Ma}$ and $400-500 \mathrm{Ma}$, and two less prominent peaks at $\sim 800 \mathrm{Ma}$ and $\sim 1800 \mathrm{Ma}$ (Robinson et al., 2004; Carrapa et al., 2014; Rittner et al., 2016). The Sonpan-Ganzi has four peaks, at $\sim 200-300 \mathrm{Ma}$, $\sim 400-500 \mathrm{Ma}, \sim 700-900 \mathrm{Ma}$ and $\sim 1800-2000 \mathrm{Ma}$ (Ding et al., 2013).

The distribution of zircon U-Pb ages of sample KLY-1 is more similar to those of the West Kunlun and the Songpan-Ganzi terranes than those of the Pamir Plateau (Figure 6). The two contemporaneous rivers in this region (the Tiznip and Karakax) provide more information on the source of KLY-1. The Tiznip River originates from the south of the West Kunlun and flows northwards into the Tarim Basin via the northern West Kunlun. The Karakax River originates from the Sonpan-Ganzi and flows northward into the Tarim Basin via the West Kunlun. The detrital zircon $\mathrm{U} / \mathrm{Pb}$ ages of Tiznip River sediments have two peaks, at $\sim 200-300$ and $\sim 400-500 \mathrm{Ma}$, while detrital zircon $\mathrm{U} / \mathrm{Pb}$ ages of the Karakax River have a relatively shorter peak at 200-300 Ma (see further details in Blayney et al., 2016). Sample KLY-1 lacks ages of $\sim 200-300 \mathrm{Ma}$, and thus shows greater similarity to the Karakax River (Figure 6). The MDS analyses also show that KLY1 is much closer to sample 1,363 from the Karakax River when compared to sample 1,344 from the Tiznip River (Figure 7). These observations suggest that sediments in KLY-1 may have had a multi-component source, from the Sonpan-Ganzi and the West Kunlun. Previously published results from other sections in the SW Tarim Basin before the Eocene show that detrital zircon $\mathrm{U} / \mathrm{Pb}$ ages have two peaks, at $\sim 200-300$ and $\sim 400-500 \mathrm{Ma}$, which should correspond to sources in the Sonpan-Ganzi, the West Kunlun and/or the North Pamir (Figure 8). In the Dashtijum section of the Tajik Basin, detrital zircon $\mathrm{U} / \mathrm{Pb}$ ages of the Late Cretaceous sample have a main peak of $\sim 200-300 \mathrm{Ma}$, which likely corresponds to a source region in the North Pamir (Chapman et al., 2019) (Figure 8). The detrital zircon U/Pb ages of the sample DZ-04 in the Asku section are more similar to the Pamir region than to the Tian Shan (Figure 11 in Sun et al., 2020).

The obvious zircon $\mathrm{U} / \mathrm{Pb}$ age peak at $\sim 45 \mathrm{Ma}$ is similar to the Central Pamir rather than other terranes (Figure 8). Moreover, MDS analyses show that the detrital zircon U/Pb ages of KLY-3 and KLY-7 are more similar to the Central Pamir, than to the North or the South Pamir (Figure 7). The detrital zircon $\mathrm{U} / \mathrm{Pb}$ age and $\varepsilon H f(t)$ analyses also provide additional evidence for the Central Pamir as the sediment source (Zhang et al., 2019). Sun et al. (2016b) suggested that the Early Eocene sedimentary change originated from the Kohistan-Ladakh arc. The detrital zircon $\mathrm{U} / \mathrm{Pb}$ age and $\varepsilon \mathrm{Hf}(\mathrm{t})$ data from the Kohistan-Ladakh arc and the Central Pamir overlap to some extent, but further research indicated that the Early Eocene sediments originated from the Central Pamir rather than the Kohistan-Ladakh arc (Zhang et al., 2019). In addition to constraining the sedimentary source from the Central Pamir, the other sediment sources in the Keliyang section after the Eocene were likely located in the West Kunlun (Figure 6 and Figure 8). Previous research also confirms that other sources were derived from the West Kunlun and/or the North Pamir in the Tajik and SW Tarim basins (Chapman et al., 2019; Zhang et al., 2019).

\section{Implications for Eocene Initial Uplift of the Central Pamir}

Based on the evidence and discussion above, Eocene sediments with the detrital zircon $\mathrm{U} / \mathrm{Pb}$ age peak at $\sim 45 \mathrm{Ma}$ were derived from the Central Pamir. This result requires rapid uplift of the 


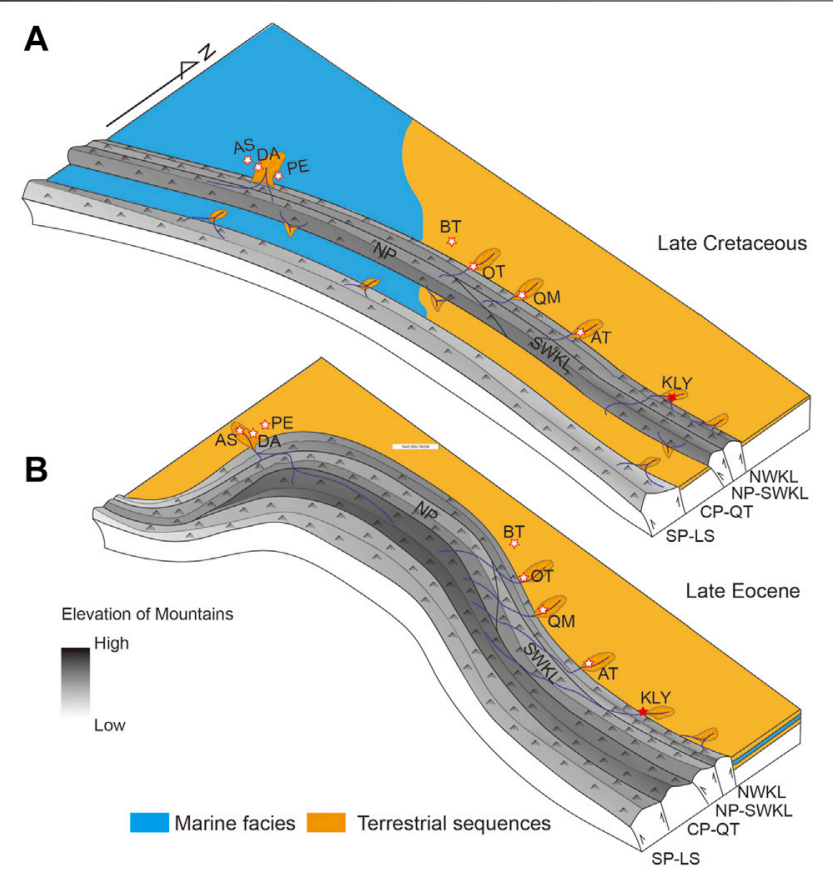

FIGURE 9 | Simplified tectonic evolution models of Pamir-West Kunlun. (A) During the Late Cretaceous, West Kunlun had a moderate paleo-elevation and was the main sediment source to the SW Tarim Basin. The Central Pamir region was occupied by shallow seas. (B) During the Late Eocene, the Central Pamir experienced rapid uplift and attained a higher paleo-elevation than that of the present-day West Kunlun, providing new sediments to the Tajik and Tarim basins. NWKL $=$ North West Kunlun; NP-SWKL $=$ North Pamir-Southern West Kunlun; CP-QT = Central Pamir-Qiang Tang; SP-LS = South Pamir - Lhasa; DA = Dashtijum section; $A S=$ Asku section; $P E$ = Peshtova section; $\mathrm{BT}=$ Bora Tokay section; $\mathrm{OT}=$ Oytag section; $\mathrm{QM}=$ Qimugen section; $A T=$ Aertashi section; $K Y=$ Keliyang section.

Central Pamir. Following this uplift, clasts were eroded from the new uplands of the Central Pamir.

These interpretations are supported by other evidence. Lowtemperature thermochronology is widely used to reconstruct fast exhumation of mountains (Bernet et al., 2006). Unfortunately, no Eocene thermochronology results are available from within the Central Pamir, perhaps due to the overprinting of later tectonic events (Ducea et al., 2003), complete erosion (Zhang et al., 2019) or nondetection (Zhang et al., 2019). However, the Late Eocene ( $\sim 37 \mathrm{Ma}$ ) component of detrital apatite fission-track ages is detected in the Keliyang section of the SW Tarim Basin (this study) and in the Peshtova section of the Tajik Basin (Wang et al., 2019) (Table 2), where sediments were likely sourced from the Central Pamir. Moreover, abundant Eocene igneous rocks from $41 \mathrm{Ma}$ to $36 \mathrm{Ma}$ (with a peak age of $40 \mathrm{Ma}$ ) were reported within the Central Pamir, and were interpreted as a result of mantle drip or lithospheric delamination (Chapman et al., 2018b). Contemporaneous metamorphic peak ages are also detected within the Central Pamir domes (Smit et al., 2014; Stearns et al., 2015; Rutte et al., 2017; Chapman et al., 2018a). The prograde metamorphic monazite age obtained for lower-crustal xenoliths in the Miocene volcanic rocks is
$50 \mathrm{Ma}$, which indicates that crustal thickening and plateau formation were already occurring during the Paleocene-Eocene in the Central Pamir (Ducea et al., 2003). Furthermore, the very short lag time between the youngest detrital apatite fission-track age component $(\sim 36 \mathrm{Ma})$ and the deposition age $(\sim 32 \mathrm{Ma})$ of the Keliyang section indicates that the Central Pamir experienced rapid uplift during the Eocene, caused by crustal thickening, which yielded large amounts of sediment to the Tarim and Tajik basins (Blayney et al., 2019; Kaya et al., 2019).

The Eocene rapid uplift event is also confirmed in other regions along the strike of the Central Pamir. Apatite fissiontrack and $\mathrm{U}-\mathrm{Th} / \mathrm{He}$ ages of the Qiangtang terrane are concentrated at around $40 \mathrm{Ma}$, suggesting that the Qiangtang terrane formed a plateau during the Eocene (Rohrmann et al., 2012). Paleoaltimetry shows that the Gonjo Basin within the Qiangtang terrane experienced rapid uplift during the Eocene (Xiong et al., 2020). Moreover, this Eocene rapid uplift event was also reconstructed in the North Pamir, based on bedrock apatite and zircon U/Th-He ages (Amidon and Hynek, 2010). In contrast, the West Kunlun experienced slow exhumation, with a paleo-elevation similar to that during the Mesozoic (Sobel and Dumitru, 1997; Cao et al., 2015; Blayney et al., 2016; Li et al., 2019). During the Eocene, the Central Pamir was uplifted to a paleo-elevation no lower than that of the present-day West Kunlun, and provided sediments to the SW Tarim Basin.

We provide an evolution model for the Pamir-West Kunlun area from the Late Cretaceous to the Late Eocene. During the Late Cretaceous (Figure 9A), the West Kunlun, with moderate paleo-elevation, was the main sedimentary source to the SW Tarim Basin, and the North Pamir was the main source to the Tajik Basin. The Central Pamir had not formed, and was connected with the Paratethys Ocean. During the Late Eocene (Figure 9B), the northward indentation of the Pamir region caused deformation at the western and eastern margins, and the Central Pamir region experienced rapid uplift to reach a paleo-elevation higher than the modern West Kunlun. Sedimentary materials from the newly-formed Central Pamir were transported by rivers into the Tarim and Tajik basins.

\section{CONCLUSION}

The SW Tarim Basin and Tajik Basin are foreland basins which developed adjacent to the Pamir-West Kunlun Mountain belts. Therefore, detailed studies of the sedimentary provenance in these basins can be used to constrain the tectonic evolution of the Pamir-West Kunlun. Detrital apatite fission track and zircon $\mathrm{U} / \mathrm{Pb}$ ages in the Keliyang section, together with previous studies in the SW Tarim and Tajik basins, constrain potential sedimentary provenance changes. We reach the following conclusions.

1) A detrital zircon $\mathrm{U} / \mathrm{Pb}$ age peak at $\sim 45 \mathrm{Ma}$ was detected in sediments deposited since the Eocene in the Keliyang section. 
Non-metric multi-dimensional scaling (MDS) shows that the Central Pamir region was likely to have been the sediment source for the Keliyang section during the Eocene.

2) The Eocene sedimentary provenance change was detected in both the SW Tarim and Tajik basins, and is supported by previous studies. This change provides a key indicator for the initial uplift of the Central Pamir.

\section{DATA AVAILABILITY STATEMENT}

The original contributions presented in the study are included in the article/Supplementary Material, further inquiries can be directed to the corresponding author.

\section{AUTHOR CONTRIBUTIONS}

This manuscript was written by PW. This manuscript was designed by DL. This manuscript was supported by funds from DL and HL. This manuscript was revised by M-LC. The apatite fission track data were measured by YW. Other co-authors attended the field work, including JP, YZ, CG, MB, and SW.

\section{FUNDING}

This work was co-supported by the National Natural Science Foundation of China (41872212, 41941016), the Key Special

\section{REFERENCES}

Amidon, W. H., and Hynek, S. A. (2010). Exhumational History of the north central Pamir. Tectonics 29, 1-13. doi:10.1029/2009tc002589

Angiolini, L., Zanchi, A., Zanchetta, S., Nicora, A., and Vezzoli, G. (2013). The Cimmerian Geopuzzle: New Data from South Pamir. Terra Nova 25, 352-360. doi:10.1111/ter.12042

Bernet, M., van der Beek, P., Pik, R., Huyghe, P., Mugnier, J.-L., Labrin, E., et al. (2006). Miocene to Recent Exhumation of the central Himalaya Determined from Combined Detrital Zircon Fission-Track and U/Pb Analysis of Siwalik Sediments, Western Nepal. Basin Res. 18, 393-412. doi:10.1111/j.13652117.2006.00303.x

Bershaw, J., Garzione, C. N., Schoenbohm, L., Gehrels, G., and Tao, L. (2012). Cenozoic Evolution of the Pamir Plateau Based on Stratigraphy, Zircon Provenance, and Stable Isotopes of Foreland basin Sediments at Oytag (Wuyitake) in the Tarim Basin (West China). J. Asian Earth Sci. 44, 136-148. doi:10.1016/j.jseaes.2011.04.020

Black, L. P., Kamo, S. L., Allen, C. M., Aleinikoff, J. N., Davis, D. W., Korsch, R. J., et al. (2003). TEMORA 1: a New Zircon Standard for Phanerozoic U-Pb Geochronology. Chem. Geology 200, 155-170. doi:10.1016/S0009-2541(03) 00165-7

Blayney, T., Dupont-Nivet, G., Najman, Y., Proust, J. N., Meijer, N., Roperch, P., et al. (2019). Tectonic Evolution of the Pamir Recorded in the Western Tarim Basin (China): Sedimentologic and Magnetostratigraphic Analyses of the Aertashi Section. Tectonics 38, 492-515. doi:10.1029/2018tc005146

Blayney, T., Najman, Y., Dupont-Nivet, G., Carter, A., Millar, I., Garzanti, E., et al. (2016). Indentation of the Pamirs with Respect to the Northern Margin of Tibet: Constraints from the Tarim basin Sedimentary Record. Tectonics 35, 2345-2369. doi:10.1002/2016tc004222

Bosboom, R., Dupont-Nivet, G., Grothe, A., Brinkhuis, H., Villa, G., Mandic, O., et al. (2014). Timing, Cause and Impact of the Late Eocene Stepwise Sea Retreat
Project for Introduced Talents Team of Southern Marine Science and Engineering Guangdong Laboratory (Guangzhou) (GML2019ZD0201), the second Tibetan Plateau Scientific Expedition of the Ministry of Science and Technology of China (2019QZKK0901), the China Geological Survey project (DD20190059, DD20190057) and CSC grant (201809110053).

\section{ACKNOWLEDGMENTS}

We thank laboratory managers from ArF laser ablation system (GeolasPlus) at the China University of Geosciences (Wuhan) and Rock-Mineral Preparation and Fission Track Dating laboratory of Geochemical Analysis and Testing Center, Northwest Institute of EcoEnvironment and Resources, Chinese Academy of Sciences. We sincerely thank Editor Dr. Yibo Yang, Dr. Xiubin Lin, Dr. Xin Wang and Dr. Honghong Wei for their constructive comments. We thank Dave Chandler from GeoEditing for his entire paper review and writing improvement.

\section{SUPPLEMENTARY MATERIAL}

The Supplementary Material for this article can be found online at: https:/www.frontiersin.org/articles/10.3389/feart.2021.741194/ full\#supplementary-material

from the Tarim Basin (West China). Palaeogeogr. Palaeoclimatol. Palaeoecol. 403, 101-118. doi:10.1016/j.palaeo.2014.03.035

Bosboom, R., Mandic, O., Dupont-Nivet, G., Proust, J.-N., Ormukov, C., and Aminov, J. (2017). Late Eocene Palaeogeography of the Proto-Paratethys Sea in Central Asia (NW China, Southern Kyrgyzstan and SW Tajikistan). Geol. Soc. Lond. Spec. Publications 427, 565-588. doi:10.1144/sp427.11

Cao, K., Wang, G.-C., Bernet, M., van der Beek, P., and Zhang, K.-X. (2015). Exhumation History of the West Kunlun Mountains, Northwestern Tibet: Evidence for a Long-Lived, Rejuvenated Orogen. Earth Planet. Sci. Lett. 432, 391-403. doi:10.1016/j.epsl.2015.10.033

Cao, K., Xu, Y., Wang, G., Zhang, K., van der Beek, P., Wang, C., et al. (2014). Neogene Source-To-Sink Relations between the Pamir and Tarim Basin: Insights from Stratigraphy, Detrital Zircon Geochronology, and Whole-Rock Geochemistry. J. Geology 122, 433-454. doi:10.1086/676478

Carrapa, B., DeCelles, P. G., Wang, X., Clementz, M. T., Mancin, N., Stoica, M., et al. (2015). Tectono-climatic Implications of Eocene Paratethys Regression in the Tajik basin of central Asia. Earth Planet. Sci. Lett. 424, 168-178. doi:10.1016/j.epsl.2015.05.034

Carrapa, B., Mustapha, F. S., Cosca, M., Gehrels, G., Schoenbohm, L. M., Sobel, E. R., et al. (2014). Multisystem Dating of Modern River Detritus from Tajikistan and China: Implications for Crustal Evolution and Exhumation of the Pamir. Lithosphere 6, 443-455. doi:10.1130/1360.1

Caves, J. K., Sjostrom, D. J., Mix, H. T., Winnick, M. J., and Chamberlain, C. P. (2014). Aridification of Central Asia and Uplift of the Altai and Hangay Mountains, Mongolia: Stable Isotope Evidence. Am. J. Sci. 314, 1171-1201. doi:10.2475/08.2014.01

Cawood, P. A., Hawkesworth, C. J., and Dhuime, B. (2012). Detrital Zircon Record and Tectonic Setting. Geology 40, 875-878. doi:10.1130/G32945.1

Chapman, J. B., Carrapa, B., DeCelles, P. G., Worthington, J., Mancin, N., Cobianchi, M., et al. (2019). The Tajik Basin: a Composite Record of Sedimentary basin Evolution in Response to Tectonics in the Pamir. Basin Res. 32, 525-545. doi:10.1111/bre.12381 
Chapman, J. B., Robinson, A. C., Carrapa, B., Villarreal, D., Worthington, J., DeCelles, P. G., et al. (2018a). Cretaceous Shortening and Exhumation History of the South Pamir Terrane. Lithosphere 10, 494-511. doi:10.1130/1691.1

Chapman, J. B., Scoggin, S. H., Kapp, P., Carrapa, B., Ducea, M. N., Worthington, J., et al. (2018b). Mesozoic to Cenozoic Magmatic History of the Pamir. Earth Planet. Sci. Lett. 482, 181-192. doi:10.1016/ j.epsl.2017.10.041

Chen, X., Chen, H., Lin, X., Cheng, X., Yang, R., Ding, W., et al. (2018). Arcuate Pamir in the Paleogene? Insights from a Review of Stratigraphy and Sedimentology of the basin Fills in the Foreland of NE Chinese Pamir, Western Tarim Basin. Earth-Science Rev. 180, 1-16. doi:10.1016/j.earscirev.2018.03.003

Cheng, X., Lei, G., Chen, H., Du, Z., Liao, L., Luo, J., et al. (2011). Cenozoic Structural Deformation of the Fusha-Keliyang Area in the piedmont of the Western Kunlun Mountains and its Control on Hydrocarbon Accumulation. Acta Petrolei Sinica 32, 83-89. doi:10.7623/syxb201101012 (in Chinese with English abstract).

Clift, P. D., Zheng, H., Carter, A., Böning, P., Jonell, T. N., Schorr, H., et al. (2017). Controls on Erosion in the Western Tarim Basin: Implications for the Uplift of Northwest Tibet and the Pamir. Geosphere 13, 1747-1765. doi:10.1130/ ges01378.1

Cowgill, E. (2009). Cenozoic Right-Slip Faulting along the Eastern Margin of the Pamir Salient, Northwestern China. Geol. Soc. America Bull. 122, 145-161. doi:10.1130/b26520.1

Cowgill, E., Yin, A., Harrison, T. M., and Xiao-Feng, W. (2003). Reconstruction of the Altyn Tagh Fault Based on U-Pb Geochronology: Role of Back Thrusts, Mantle Sutures, and Heterogeneous Crustal Strength in Forming the Tibetan Plateau. J. Geophys. Res. 108, 1-28. doi:10.1029/2002JB002080

Dickinson, W. R., Beard, L. S., Brackenbridge, G. R., Erjavec, J. L., Ferguson, R. C., Inman, K. F., et al. (1983). Provenance of North-American Phanerozoic Sandstones in Relation to Tectonic Setting. Geol. Soc. America Bull. 94, 222-235. doi:10.1130/0016-7606(1983)94<222: Ponaps $>2.0 . \mathrm{CO} ; 2$

Dickinson, W. R., and Gehrels, G. E. (2009). Use of U-Pb Ages of Detrital Zircons to Infer Maximum Depositional Ages of Strata: A Test against a Colorado Plateau Mesozoic Database. Earth Planet. Sci. Lett. 288, 115-125. doi:10.1016/ j.epsl.2009.09.013

Ding, L., Yang, D., Cai, F. L., Pullen, A., Kapp, P., Gehrels, G. E., et al. (2013). Provenance Analysis of the Mesozoic Hoh-Xil-Songpan-Ganzi Turbidites in Northern Tibet: Implications for the Tectonic Evolution of the Eastern PaleoTethys Ocean. Tectonics 32, 34-48. doi:10.1002/tect.20013

Ducea, M. N., Lutkov, V., Minaev, V. T., Hacker, B., Ratschbacher, L., Luffi, P., et al. (2003). Building the Pamirs: The View from the Underside. Geol. 31, 849-852. doi:10.1130/G19707.1

Huber, M., and Goldner, A. (2012). Eocene Monsoons. J. Asian Earth Sci. 44, 3-23. doi:10.1016/j.jseaes.2011.09.014

Kaya, M. Y., Dupont-Nivet, G., Proust, J. N., Roperch, P., Bougeois, L., Meijer, N., et al. (2019). Paleogene Evolution and Demise of the proto-Paratethys Sea in Central Asia (Tarim and Tajik Basins): Role of Intensified Tectonic Activity at Ca. 41 Ma. Basin Res. 31, 461-486. doi:10.1111/bre.12330

Kufner, S.-K., Schurr, B., Sippl, C., Yuan, X., Ratschbacher, L., Akbar, A. s. o. M., et al. (2016). Deep India Meets Deep Asia: Lithospheric Indentation, Delamination and Break-Off under Pamir and Hindu Kush (Central Asia). Earth Planet. Sci. Lett. 435, 171-184. doi:10.1016/j.epsl.2015.11.046

Li, C., Chen, H., Zhang, F., Lin, X., Cheng, X., Li, Y., et al. (2021). Cenozoic basinfilling Evolution of the SW Tarim Basin and its Implications for the Uplift of Western Kunlun: Insights from (Seismo)stratigraphy. Palaeogeogr. Palaeoclimatol. Palaeoecol. 562, 110149. doi:10.1016/j.palaeo.2020.110149

Li, G., Sandiford, M., Fang, A., Kohn, B., Sandiford, D., Fu, B., et al. (2019). Multistage Exhumation History of the West Kunlun Orogen and the Amalgamation of the Tibetan Plateau. Earth Planet. Sci. Lett. 528, 115833. doi:10.1016/ j.epsl.2019.115833

Li, Y.-P., Robinson, A. C., Gadoev, M., and Oimuhammadzoda, I. (2020). Was the Pamir Salient Built along a Late Paleozoic Embayment on the Southern Asian Margin? Earth Planet. Sci. Lett. 550, 116554. doi:10.1016/j.epsl.2020.116554

Licht, A., van Cappelle, M., Abels, H. A., Ladant, J.-B., Trabucho-Alexandre, J., France-Lanord, C., et al. (2014). Asian Monsoons in a Late Eocene Greenhouse World. Nature 513, 1-6. doi:10.1038/nature13704
Liu, D., Li, H., Sun, Z., Cao, Y., Wang, L., Pan, J., et al. (2017). Cenozoic Episodic Uplift and Kinematic Evolution between the Pamir and Southwestern Tien Shan. Tectonophysics 712-713, 438-454. doi:10.1016/j.tecto.2017.06.009

Liu, Z., Jiang, Y.-H., Jia, R.-Y., Zhao, P., and Zhou, Q. (2015). Origin of Late Triassic High-K Calc-Alkaline Granitoids and Their Potassic Microgranular Enclaves from the Western Tibet Plateau, Northwest China: Implications for PaleoTethys Evolution. Gondwana Res. 27, 326-341. doi:10.1016/j.gr.2013.09.022

Lukens, C. E., Carrapa, B., Singer, B. S., and Gehrels, G. (2012). Miocene Exhumation of the Pamir Revealed by Detrital Geothermochronology of Tajik Rivers. Tectonics 31, 1-12. doi:10.1029/2011tc003040

Matte, P., Tapponnier, P., Arnaud, N., Bourjot, L., Avouac, J. P., Vidal, P., et al. (1996). Tectonics of Western Tibet, between the Tarim and the Indus. Earth Planet. Sci. Lett. 142, 311-330. doi:10.1016/0012-821X(96)00086-6

Molnar, P., Boos, W. R., and Battisti, D. S. (2010). Orographic Controls on Climate and Paleoclimate of Asia: Thermal and Mechanical Roles for the Tibetan Plateau. Annu. Rev. Earth Planet. Sci. 38, 77-102. doi:10.1146/annurev-earth040809-152456

Molnar, P., and Tapponnier, P. (1975). Cenozoic Tectonics of Asia: Effects of a Continental Collision: Features of Recent continental Tectonics in Asia Can Be Interpreted as Results of the India-Eurasia Collision. Science 189, 419-426. doi:10.1126/science.189.4201.419

Nie, J., Peng, W., Möller, A., Song, Y., Stockli, D. F., Stevens, T., et al. (2014). Provenance of the Upper Miocene-Pliocene Red Clay Deposits of the Chinese Loess Plateau. Earth Planet. Sci. Lett. 407, 35-47. doi:10.1016/j.epsl.2014.09.026

Rittner, M., Vermeesch, P., Carter, A., Bird, A., Stevens, T., Garzanti, E., et al. (2016). The Provenance of Taklamakan Desert Sand. Earth Planet. Sci. Lett. 437, 127-137. doi:10.1016/j.epsl.2015.12.036

Robinson, A. C., Ducea, M., and Lapen, T. J. (2012). Detrital Zircon and Isotopic Constraints on the Crustal Architecture and Tectonic Evolution of the Northeastern Pamir. Tectonics 31, 1-16. doi:10.1029/2011tc003013

Robinson, A. C., Yin, A., Manning, C. E., Harrison, T. M., Zhang, S.-H., and Wang, X.-F. (2004). Tectonic Evolution of the Northeastern Pamir: Constraints from the Northern Portion of the Cenozoic Kongur Shan Extensional System, Western China. Geol. Soc. America Bull. 116, 953-973. doi:10.1130/b25375.1

Rohrmann, A., Kapp, P., Carrapa, B., Reiners, P. W., Guynn, J., Ding, L., et al. (2012). Thermochronologic Evidence for Plateau Formation in central Tibet by 45 Ma. Geology 40, 187-190. doi:10.1130/g32530.1

Rutte, D., Ratschbacher, L., Schneider, S., Stübner, K., Stearns, M. A., Gulzar, M. A., et al. (2017). Building the Pamir-Tibetan Plateau-Crustal Stacking, Extensional Collapse, and Lateral Extrusion in the Central Pamir: 1. Geometry and Kinematics. Tectonics 36, 342-384. doi:10.1002/2016tc004293

Schmidt, J., Hacker, B. R., Ratschbacher, L., Stübner, K., Stearns, M., KylanderClark, A., et al. (2011). Cenozoic Deep Crust in the Pamir. Earth Planet. Sci. Lett. 312, 411-421. doi:10.1016/j.epsl.2011.10.034

Schwab, M., Ratschbacher, L., Siebel, W., McWilliams, M., Minaev, V., Lutkov, V., et al. (2004). Assembly of the Pamirs: Age and Origin of Magmatic Belts from the Southern Tien Shan to the Southern Pamirs and Their Relation to Tibet. Tectonics 23, 1-31. doi:10.1029/2003tc001583

Shaanxi Geological Bureau (2006). Geological Map of the Qiaha Area, 1. Beijing scale: Geological Press, 250. 000.

Si, J., Li, H., Barrier, L., van Der Word, J., Sun, Z., Pei, J., et al. (2007). Late Cenozoic Uplift Characteristics of the Northwestern Margin of the Qinghai Tibet Plateau: Evidence from Sedimentology of the Piedmont basin of the West Kunlun Mountains. Geol. Bull. China 26, 1356-1367. (in Chinese with English Abstract).

Smit, M. A., Ratschbacher, L., Kooijman, E., and Stearns, M. A. (2014). Early Evolution of the Pamir Deep Crust from Lu-Hf and U-Pb Geochronology and Garnet Thermometry. Geology 42, 1047-1050. doi:10.1130/G35878.1

Sobel, E. R. (1999). Basin Analysis of the Jurassic-Lower Cretaceous Southwest Tarim basin, Northwest China. GSA Bull. 11, 709-724. doi:10.1130/0016-7606(1999)1112.3.CO;2

Sobel, E. R., Chen, J., Schoenbohm, L. M., Thiede, R., Stockli, D. F., Sudo, M., et al. (2013). Oceanic-style Subduction Controls Late Cenozoic Deformation of the Northern Pamir Orogen. Earth Planet. Sci. Lett. 363, 204-218. doi:10.1016/ j.epsl.2012.12.009

Sobel, E. R., and Dumitru, T. A. (1997). Thrusting and Exhumation Around the Margins of the Western Tarim basin during the India-Asia Collision. J. Geophys. Res. 102, 5043-5063. doi:10.1029/96JB03267 
Stearns, M. A., Hacker, B. R., Ratschbacher, L., Rutte, D., and Kylander-Clark, A. R. C. (2015). Titanite Petrochronology of the Pamir Gneiss Domes: Implications for Middle to Deep Crust Exhumation and Titanite Closure to $\mathrm{Pb}$ and $\mathrm{Zr}$ Diffusion. Tectonics 34, 784-802. doi:10.1002/2014tc003774

Sun, J., Alloway, B., Fang, X., and Windley, B. F. (2015). Refuting the Evidence for an Earlier Birth of the Taklimakan Desert. Proc. Natl. Acad. Sci. USA 112, E5556-E5557. doi:10.1073/pnas.1517525112

Sun, J., and Liu, T. (2006). The Age of the Taklimakan Desert. Science 312, 1621. doi:10.1126/science.1124616

Sun, J., Windley, B. F., Zhang, Z., Fu, B., and Li, S. (2016a). Diachronous Seawater Retreat from the Southwestern Margin of the Tarim Basin in the Late Eocene. J. Asian Earth Sci. 116, 222-231. doi:10.1016/j.jseaes.2015.11.020

Sun, J., Xiao, W., Windley, B. F., Ji, W., Fu, B., Wang, J., et al. (2016b). Provenance Change of Sediment Input in the Northeastern Foreland of Pamir Related to Collision of the Indian Plate with the Kohistan-Ladakh Arc at Around $47 \mathrm{Ma}$. Tectonics 35, 315-338. doi:10.1002/2015tc003974

Sun, J., Zhang, Z., Cao, M., Windley, B. F., Tian, S., Sha, J., et al. (2020). Timing of Seawater Retreat from Proto-Paratethys, Sedimentary Provenance, and Tectonic Rotations in the Late Eocene-Early Oligocene in the Tajik Basin, Central Asia. Palaeogeogr. Palaeoclimatol. Palaeoecol. 545, 109657. doi:10.1016/ j.palaeo.2020.109657

Sun, X., Tian, Y., Kuiper, K. F., Li, C. a., Zhang, Z., and Wijbrans, J. R. (2021). No Yangtze River Prior to the Late Miocene: Evidence from Detrital Muscovite and K-Feldspar 40 Ar/39 Ar Geochronology. Geophys. Res. Lett. 48, 1-15. doi:10.1029/2020gl089903

Vermeesch, P. (2013). Multi-sample Comparison of Detrital Age Distributions. Chem. Geology 341, 140-146. doi:10.1016/j.chemgeo.2013.01.010

Wang, L., Shen, L., Liu, C., and Ding, L. (2020). Evolution of the Paleo-Mekong River in the Early Cretaceous: Insights from the Provenance of Sandstones in the Vientiane Basin, central Laos. Palaeogeogr. Palaeoclimatol. Palaeoecol. 545, 109651. doi:10.1016/j.palaeo.2020.109651

Wang, X., Carrapa, B., Chapman, J. B., Henriquez, S., Wang, M., DeCelles, P. G., et al. (2019). Parathethys Last Gasp in Central Asia and Late Oligocene Accelerated Uplift of the Pamirs. Geophys. Res. Lett. 46, 11773-11781. doi:10.1029/2019gl084838

Wang, X., Sun, D., Chen, F., Wang, F., Li, B., Popov, S. V., et al. (2014). Cenozoic Paleo-Environmental Evolution of the Pamir-Tien Shan Convergence Zone. J. Asian Earth Sci. 80, 84-100. doi:10.1016/ j.jseaes.2013.10.027

Wei, H.-H., Meng, Q.-R., Ding, L., and Li, Z.-Y. (2013). Tertiary Evolution of the Western Tarim basin, Northwest China: A Tectono-Sedimentary Response to Northward Indentation of the Pamir Salient. Tectonics 32, 558-575. doi:10.1002/tect.20046

Xiao, W., Han, F., Windley, B. F., Yuan, C., Zhou, H., and Li, J. (2003). Multiple Accretionary Orogenesis and Episodic Growth of Continents: Insights from the Western Kunlun Range, Central Asia. Int. Geology. Rev. 45, 303-328. doi:10.2747/0020-6814.45.4.303

Xiao, W. J., Windley, B. F., Chen, H. L., Zhang, G. C., and Li, J. L. (2002). Carboniferous-Triassic Subduction and Accretion in the Western Kunlun, China: Implications for the Collisional and Accretionary Tectonics of the Northern Tibetan Plateau. Geology 30, 295-298. doi:10.1130/00917613(2002)030<0295:CTSAAI >2.0.CO;2
Xiong, Z., Ding, L., Spicer, R. A., Farnsworth, A., Wang, X., Valdes, P. J., et al. (2020). The Early Eocene Rise of the Gonjo Basin, SE Tibet: From Low Desert to High forest. Earth Planet. Sci. Lett. 543, 1-13. doi:10.1016/j.epsl.2020.116312

Yang, W., Jolivet, M., Dupont-Nivet, G., and Guo, Z. (2014). Mesozoic - Cenozoic Tectonic Evolution of Southwestern Tian Shan: Evidence from Detrital Zircon $\mathrm{U} / \mathrm{Pb}$ and Apatite Fission Track Ages of the Ulugqat Area, Northwest China. Gondwana Res. 26, 986-1008. doi:10.1016/j.gr.2013.07.020

Yang, Y., and Liu, M. (2002). Cenozoic Deformation of the Tarim Plate and the Implications for Mountain Building in the Tibetan Plateau and the Tian Shan. Tectonics 21, 1-17. doi:10.1029/2001tc001300

Yin, A., and Harrison, T. M. (2000). Geologic Evolution of the Himalayan-Tibetan Orogen. Annu. Rev. Earth Planet. Sci. 28, 211-280. doi:10.1146/ annurev.earth.28.1.211

Yin, A., Rumelhart, P. E., Butler, R., Cowgill, E., Harrison, T. M., Foster, D. A., et al. (2002). Tectonic History of the Altyn Tagh Fault System in Northern Tibet Inferred from Cenozoic Sedimentation. GSA Bull. 114, 1257-1295. doi:10.1130/ 0016-7606(2002)114<1257:THOTAT >2.0.CO;2

Zhang, S., Hu, X., and Garzanti, E. (2019). Paleocene Initial Indentation and Early Growth of the Pamir as Recorded in the Western Tarim Basin. Tectonophysics 772, 1-16. doi:10.1016/j.tecto.2019.228207

Zhang, Z., Wang, H., Guo, Z., and Jiang, D. (2007a). Impacts of Tectonic Changes on the Reorganization of the Cenozoic Paleoclimatic Patterns in China. Earth Planet. Sci. Lett. 257, 622-634. doi:10.1016/j.epsl.2007.03.024

Zhang, Z., Wang, H., Guo, Z., and Jiang, D. (2007b). What Triggers the Transition of Palaeoenvironmental Patterns in China, the Tibetan Plateau Uplift or the Paratethys Sea Retreat?. Palaeogeogr. Palaeoclimatol. Palaeoecol. 245, 317-331. doi:10.1016/j.palaeo.2006.08.003

Zheng, H., Wei, X., Tada, R., Clift, P. D., Wang, B., Jourdan, F., et al. (2015a). Late Oligocene-Early Miocene Birth of the Taklimakan Desert. Proc. Natl. Acad. Sci. USA 112, 7662-7667. doi:10.1073/pnas.1424487112

Zheng, H., Wei, X., Tada, R., Clift, P. D., Wang, B., Jourdan, F., et al. (2015b). Reply to Sun et al.: Confirming the evidence for Late Oligocene-Early Miocene birth of the Taklimakan Desert. Proc. Natl. Acad. Sci. USA 112, E5558-E5559. doi:10.1073/pnas.1517735112

Conflict of Interest: The authors declare that the research was conducted in the absence of any commercial or financial relationships that could be construed as a potential conflict of interest.

Publisher's Note: All claims expressed in this article are solely those of the authors and do not necessarily represent those of their affiliated organizations or those of the publisher, the editors, and the reviewers. Any product that may be evaluated in this article, or claim that may be made by its manufacturer, is not guaranteed or endorsed by the publisher.

Copyright (C) 2021 Wang, Liu, Li, Chevalier, Wang, Pan, Zheng, Ge, Bai and Wang. This is an open-access article distributed under the terms of the Creative Commons Attribution License (CC BY). The use, distribution or reproduction in other forums is permitted, provided the original author(s) and the copyright owner(s) are credited and that the original publication in this journal is cited, in accordance with accepted academic practice. No use, distribution or reproduction is permitted which does not comply with these terms. 